Check for updates

Cite this: RSC Adv., 2021, 11, 1715

Received 2nd August 2020

Accepted 20th November 2020

DOI: 10.1039/d0ra06680j

rsc.li/rsc-advances

\section{The effect of cooling process on the structure and charge/discharge capacities of Li-rich solid- solution layered oxide cathode materials for the Li- ion battery $\dagger$}

\author{
Fumihiro Nomura, ${ }^{a}$ Tatsuya Watanabe, ${ }^{\text {a Hiroya Ochiai, }}{ }^{\text {T Takao Gunji, (D) ab }}$ \\ Takeshi Hagiwara, ${ }^{b}$ Jianfei Wu (D) ${ }^{c}$ and Futoshi Matsumoto (D) *ab
}

\begin{abstract}
The effect of cooling process after calcination at $900{ }^{\circ} \mathrm{C}$ in the preparation of cathode materials, on the crystal structure and charging/discharging capacities of $\mathrm{Li}_{2} \mathrm{MnO}_{3}-\mathrm{LiNi}_{1 / 2} \mathrm{Mn}_{1 / 2} \mathrm{O}_{2}-\mathrm{LiNi}_{1 / 3} \mathrm{Mn}_{1 / 3} \mathrm{CO}_{1 / 3} \mathrm{O}_{2} \mathrm{Li}-$ rich solid-solution layered oxide (LLO) cathode materials for the lithium ion battery was examined in twenty-one LLO samples having different compositions. This was achieved by applying two types of cooling processes: (i) quenching the calcinated LLO samples with liquid nitrogen (quenched cooling), and (ii) slow cooling of LLO samples in the furnace at a controlled decreasing rate of the temperature (slow cooling). The results of the comparison between discharging capacities observed with LLO samples prepared with two types of cooling processes indicated that the cooling process for LLO samples to exhibit high discharge capacity was not limited to either one. The process that can be more effective for LLO samples to exhibit the high discharge capacity depended on the composition of LLO samples. LLO samples containing $\mathrm{Li}_{2} \mathrm{MnO}_{3}$ of over $60 \%$ exhibited higher discharge capacity when samples were quenched with liquid nitrogen than those prepared with the slow cooling process. Among LLOs examined, the effect of quenching was maximum when the $\mathrm{Li}_{2} \mathrm{MnO}_{3}$ content was $60 \%$. As the LLO composition deviated from the line of $60 \% \mathrm{Li}_{2} \mathrm{MnO}_{3}$ in the $\mathrm{Li}\left[\mathrm{Li} 0.20 \mathrm{Mn}_{0.58} \mathrm{Ni}_{0.18} \mathrm{CO}_{0.04}\right]_{2}$ sample compositions, the effect of quenching became smaller and the slow cooling process was superior to the quenching process. A connection was thus made between the structural difference of LLO samples prepared with the two types of cooling processes and the cathode performance was observed.
\end{abstract}

\section{Introduction}

$\mathrm{Li}_{2} \mathrm{MnO}_{3}-\mathrm{LiMO}_{2}$ (M: transition metal) Li-rich solid-solution layered oxide (LLO) materials have attracted much attention from researchers and engineers in the area of lithium ion batteries (LIBs) because of their high charging/discharging capacities over $250 \mathrm{~mA} \mathrm{~h} \mathrm{~g}{ }^{-1}$ when LLO materials were charged to more than $4.6 \mathrm{~V}\left(v s . \mathrm{Li} / \mathrm{Li}^{+}\right) .{ }^{\mathbf{1}, 2}$ Although many researchers have made efforts toward elucidating the reason why the LLO materials exhibited high charging/discharging capacities, ${ }^{\mathbf{3} 4}$ the mechanism has not been made clear yet. In addition, their

${ }^{a}$ Department of Materials and Life Chemistry, Kanagawa University, 3-27-1, Rokkakubashi, Kanagawa-ku, Yokohama, Kanagawa 221-8686, Japan. E-mail: fmatsumoto@kanagawa-u.ac.jp

${ }^{b}$ Research Institute for Engineering, Kanagawa University, 3-27-1, Rokkakubashi, Kanagawa-ku, Yokohama, Kanagawa 221-8686, Japan

${ }^{c}$ Qingdao Industrial Energy Storage Research Institute, Qingdao Institute of Bioenergy and Bioprocess Technology, Chinese Academy of Sciences, No. 189 Songling Road, 266101 Qingdao, China

$\dagger$ Electronic supplementary information (ESI) available. See DOI: 10.1039/d0ra06680j capacities degrade with increasing charging/discharging cycling number. ${ }^{5,6}$ A prevention method for the degradation of the cathode performance is also not known to have been established yet. The answers of how to prepare LLO materials exhibiting high and stable capacities is still pursued. In order to establish knowledge on LLO materials from a multilateral point of view, in the LLO samples composed of $\mathrm{Li}_{2} \mathrm{MnO}_{3}-\mathrm{LiNi}_{1 / 2} \mathrm{Mn}_{1 / 2} \mathrm{O}_{2}-\mathrm{LiNi}_{1 /}$ ${ }_{3} \mathrm{Mn}_{1 / 3} \mathrm{Co}_{1 / 3} \mathrm{O}_{2}$, we have also examined the best ratios of $\mathrm{Li}_{2} \mathrm{MnO}_{3}$, $\mathrm{LiNi}_{1 / 2} \mathrm{Mn}_{1 / 2} \mathrm{O}_{2}$ and $\mathrm{LiNi}_{1 / 3} \mathrm{Mn}_{1 / 3} \mathrm{Co}_{1 / 3} \mathrm{O}_{2}$, the calcination temperature and the cooling process for LLO exhibiting the best cathode performance. ${ }^{7-10}$ Among these results, it was found that $\mathrm{Li}$

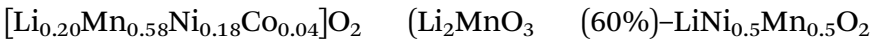
$\left.(30 \%)-\mathrm{LiNi}_{1 / 3} \mathrm{Co}_{1 / 3} \mathrm{Mn}_{1 / 3} \mathrm{O}_{2}(10 \%)\right)$ exhibited the best cathode performance among LLOs examined, and the cooling process was one of the key factors in determining the cathode performance. ${ }^{10}$ Many papers have reported the use of the quenching process, in which LLO samples calcinated at $800-100{ }^{\circ} \mathrm{C}$ were suddenly cooled with liquid nitrogen; thus, the importance of quenching process in achieving LLO samples exhibiting high charging/discharging capacities has been suggested. ${ }^{\mathbf{1 1 - 1 4}}$ The difference in the crystal structures between LLO samples 
prepared with the quenched cooling process, in which calcinated LLO samples were quenched with liquid nitrogen, and the slow cooling process, in which calcinated samples were cooled in the furnace at a controlled decreasing temperature rate, have been discussed. ${ }^{12,15}$ We also have confirmed the necessity of the quenching process for the LLO samples having the composition of $\mathrm{Li}\left[\mathrm{Li}_{0.20} \mathrm{Mn}_{0.58} \mathrm{Ni}_{0.18} \mathrm{Co}_{0.04}\right] \mathrm{O}_{2}\left(\mathrm{Li}_{2} \mathrm{MnO}_{3}(55 \%)-\mathrm{LiNi}_{0.5} \mathrm{Mn}_{0.5} \mathrm{O}_{2}\right.$ $\left.(35 \%)-\mathrm{LiNi}_{1 / 3} \mathrm{Co}_{1 / 3} \mathrm{Mn}_{1 / 3} \mathrm{O}_{2}(10 \%)\right) .{ }^{10}$ In addition, quenching the LLO samples decreased the degree of stacking defaults and disordering between the $\mathrm{Li}^{+}$and transition metal ions on the transition metal layer in the crystal structure of the LLO samples, resulting in an improvement of the cathode performance. Slow cooling of the LLO samples degraded the degree of the crystal structure of the LLOs, and reduced the charging/discharging cycle performance. ${ }^{10}$ On the contrary, in the synthesis of layered lithium transition-metal oxides, $\mathrm{LiMO}_{2}(\mathrm{M}=\mathrm{Co}, \mathrm{Ni}, \mathrm{Mn})$, quenched cooling was not applied for the $\mathrm{LiMO}_{2}$ samples that exhibited high and stable cathode performance. ${ }^{16,17}$ However, there is a paper in which it has been reported that the quenched cooling process is effective in enhancing the cycle stability and storage property in Ni-rich $\mathrm{LiMO}_{2} \cdot{ }^{18}$ From these papers, we doubt that the application of the cooling processes to cathode materials can be divided into the quenched cooling for the LLO materials and slow cooling for $\mathrm{LiMO}_{2}$. So, in this study, we examined the dependence of the charging/discharging capacities on the cooling process in several LLO samples composed of $\mathrm{Li}_{2} \mathrm{MnO}_{3}-\mathrm{LiNi}_{1 /}$ ${ }_{2} \mathrm{Mn}_{1 / 2} \mathrm{O}_{2}-\mathrm{LiNi}_{1 / 3} \mathrm{Mn}_{1 / 3} \mathrm{Co}_{1 / 3} \mathrm{O}_{2}$. Except for the quenched cooling and slow cooling processes, other cooling processes are considered by changing the cooling rates. In other papers, the quenched cooling and slow cooling processes were used frequently. Therefore, in this study, the quenched cooling and slow cooling processes were examined. It could be confirmed that the necessity of quenched cooling as a cooling process was dependent on the ratio of the $\mathrm{Li}_{2} \mathrm{MnO}_{3}-\mathrm{LiNi}_{1 / 2} \mathrm{Mn}_{1 / 2} \mathrm{O}_{2}-\mathrm{LiNi}_{1 / 3} \mathrm{Mn}_{1 / 3} \mathrm{Co}_{1 / 3} \mathrm{O}_{2}$ in the LLO samples. In addition, what was changed by the difference in the cooling process in the LLO samples was analyzed. Qu et al. reported that in the quenched cooling method case, there was an increase in the interslab thickness and decrease in the degree of cation mixing in the $\mathrm{LiNi}_{0.8} \mathrm{Co}_{0.15} \mathrm{Al}_{0.05} \mathrm{O}_{2}$ sample. ${ }^{18}$ Chang et al. reported an increase in the content of the Li-rich monoclinic component, as well as a larger lattice in the quenched cooling of the $\mathrm{Li}_{1.207} \mathrm{Ni}_{0.127} \mathrm{Mn}_{0.54} \mathrm{Co}_{0.127} \mathrm{O}_{2}$ sample. ${ }^{14}$

In this study, we also gathered the information on the average crystal structure of LLO samples by the Rietveld refinement method with the pXRD patterns and the results of charging/discharging cycle tests, and tried to find the relationship between the cooling process and the cathode performance from the view point of the average crystal structure of the LLO samples with pXRD data.

\section{Experimental}

\subsection{Preparation of LLO materials}

The $\mathrm{Li}_{2} \mathrm{MnO}_{3}-\mathrm{LiNi}_{1 / 2} \mathrm{Mn}_{1 / 2} \mathrm{O}_{2}-\mathrm{LiNi}_{1 / 3} \mathrm{Mn}_{1 / 3} \mathrm{Co}_{1 / 3} \mathrm{O}_{2}$ LLO samples examined in this study were synthesized by a co-precipitation procedure using the following commercial reagents: nickel sulfate hexahydrate $\left(\mathrm{NiSO}_{4} \cdot 6 \mathrm{H}_{2} \mathrm{O}, 99 \%\right.$, Kanto Chemical. Co., Inc.
(Kanto), Japan), manganese sulfate monohydrate $\left(\mathrm{MnSO}_{4} \cdot \mathrm{H}_{2} \mathrm{O}\right.$, 99\%, Kanto) and cobalt sulfate heptahydrate $\left(\mathrm{CoSO}_{4} \cdot 7 \mathrm{H}_{2} \mathrm{O}, 99 \%\right.$, Wako Pure Chemical Industries, Ltd. (Wako), Japan). All of the reagents were used without further purification. The targeted compositions of twenty-one synthesized LLOs and the ratios of the $\mathrm{Li}_{2} \mathrm{MnO}_{3}, \mathrm{LiNi}_{1 / 2} \mathrm{Mn}_{1 / 2} \mathrm{O}_{2}$ and $\mathrm{LiNi}_{1 / 3} \mathrm{Mn}_{1 / 3} \mathrm{Co}_{1 / 3} \mathrm{O}_{2}$ components are summarized in Table 1 , and are also presented in the $\mathrm{Li}_{2} \mathrm{MnO}_{3}-\mathrm{LiNi}_{1 / 2} \mathrm{Mn}_{1 / 2} \mathrm{O}_{2}-\mathrm{LiNi}_{1 / 3} \mathrm{Mn}_{1 / 3} \mathrm{Co}_{1 / 3} \mathrm{O}_{2}$ ternary diagram of Fig. 1.

In this study, selected samples in the ternary diagrams were examined. The points to select the samples were the vertical lines and the horizon line of the composition in the ternary diagram. In the vertical lines, the ratio of $\mathrm{LiNi}_{1 / 2} \mathrm{Mn}_{1 / 2} \mathrm{O}_{2}$ to $\mathrm{LiNi}_{1 / 3} \mathrm{Mn}_{1 / 3} \mathrm{Co}_{1 /}$ ${ }_{3} \mathrm{O}_{2}$ was fixed, and then the ratio of $\mathrm{Li}_{2} \mathrm{MnO}_{3}$ to $\mathrm{LiMO}_{2}$ was changed to find the dependence of the cooling process on the ratio of $\mathrm{Li}_{2} \mathrm{MnO}_{3}$ to $\mathrm{LiMO}_{2}$. In the horizontal line in the ternary diagram, conversely, the ratio of $\mathrm{Li}_{2} \mathrm{MnO}_{3}$ was fixed, and then the ratio of $\mathrm{LiNi}_{1 / 2} \mathrm{Mn}_{1 / 2} \mathrm{O}_{2}$ to $\mathrm{LiNi}_{1 / 3} \mathrm{Mn}_{1 / 3} \mathrm{Co}_{1 / 3} \mathrm{O}_{2}$ was changed to find the dependence of cooling process on the ratio of $\mathrm{LiNi}_{1 / 2} \mathrm{Mn}_{1 / 2} \mathrm{O}_{2}$ to $\mathrm{LiNi}_{1 / 3} \mathrm{Mn}_{1 / 3} \mathrm{Co}_{1 / 3} \mathrm{O}_{2}$. The horizon line used in this examination was in the area in which the LLO samples exhibited higher charge/ discharge capacity, as mentioned above. We think that an examination of the LLO samples in the two vertical lines and a horizon line was enough to find the relationship between the cooling processes to achieve higher capacity and composition of LLO samples.

The starting material mixture of $\mathrm{MnSO}_{4} \cdot \mathrm{H}_{2} \mathrm{O}, \mathrm{NiSO}_{4} \cdot 6 \mathrm{H}_{2} \mathrm{O}$ and $\mathrm{CoSO}_{4} \cdot 7 \mathrm{H}_{2} \mathrm{O}$ with a targeted $\mathrm{Ni} / \mathrm{MN} / \mathrm{Co}$ ratio was added to $100 \mathrm{~mL}$ of water, while the total concentration of the transition metal ions in the solution was $2 \mathrm{M}$. In order to precipitate the transition metal carbonates from the solution, $80 \mathrm{~mL}$ of the $2 \mathrm{M}$ sodium carbonate $\left(\mathrm{Na}_{2} \mathrm{CO}_{3}, 98 \%\right.$, Wako) solution was injected at the rate of $0.5 \mathrm{~cm}^{3} \mathrm{~s}^{-1}$ into it (kept at $60{ }^{\circ} \mathrm{C}$ ) with a burette. During the precipitation, its $\mathrm{pH}$ was kept at 7.5 by injecting the $\mathrm{NH}_{4} \mathrm{OH}$ solution. The precipitates were filtered off, washed several times with hot water until the filtrate exhibited a neutral $\mathrm{pH}$, and dried under vacuum at $100{ }^{\circ} \mathrm{C}$ for $5 \mathrm{~h}$. Lithium carbonate $\left(\mathrm{Li}_{2} \mathrm{CO}_{3}, 98 \%\right.$, Kanto) was mixed with the precipitates using a wet planetary ball-milling machine in a Teflon jar (672 $\mathrm{mL}$ ) containing Teflon balls (diameter $1.5 \mathrm{~cm}, 88$ balls) and acetone $(80 \mathrm{~mL})$ at ambient temperature with a speed of $300 \mathrm{rpm}$ for $3 \mathrm{~h}$. To compensate for any possible losses of $\mathrm{Li}^{+}$ ions by evaporation of $\mathrm{Li}$ during the high temperature calcination, the transition metal carbonates were mixed with an excess (7.0\%) of $\mathrm{Li}_{2} \mathrm{CO}_{3}$, in comparison with the amount calculated based on the stoichiometric mole ratios of $\mathrm{Li}, \mathrm{Ni}$, Co and $\mathrm{Mn}$ in the target LLOs. After drying the mixture at $120{ }^{\circ} \mathrm{C}$ for $4 \mathrm{~h}$ under vacuum, a pellet (diameter: $2 \mathrm{~mm}$ ) of the dried mixture was formed using $30 \mathrm{kN}$ of force. The individual pellets were then calcinated at $900{ }^{\circ} \mathrm{C}$ for $12 \mathrm{~h}$ in air. Two types of cooling processes after calcination were used: one is a quenched cooling process with liquid nitrogen, while another is a slow cooling process at a controlled cooling rate of $25{ }^{\circ} \mathrm{C} \mathrm{h}^{-1}$ in the furnace from 900 to $25^{\circ} \mathrm{C}$. Hereinafter, the former cooling will be called "quenched cooling" and the latter "slow cooling". The cooled pellets were ground with a mortar to obtain particles having a surface area of $0.8-0.9 \mathrm{~m}^{2} \mathrm{~g}^{-1}$. The Li : Ni : Co : Mn elemental 
Table 1 Summary of the targeted compositions of synthesized LLO samples

\begin{tabular}{|c|c|c|c|c|}
\hline $\begin{array}{l}\text { Sample } \\
\text { no. }\end{array}$ & $\begin{array}{l}\text { Targeted compositions of } \\
\text { synthesized LLOs }\end{array}$ & $\begin{array}{l}\text { Ratios of } \mathrm{Li}_{2} \mathrm{MnO}_{3} \text {, } \\
\mathrm{LiNi}_{1 / 2} \mathrm{Mn}_{1 / 2} \mathrm{O}_{2} \text { and } \mathrm{LiNi}_{1 / 3} \mathrm{Mn}_{1 / 3} \mathrm{Co}_{1 /} \\
{ }_{3} \mathrm{O}_{2} \text { components }\end{array}$ & $\begin{array}{l}\text { Ratios of Mn, Co and Ni in } \\
\text { LLOs }\end{array}$ & $\begin{array}{l}\text { Compositions estimated with } \\
\text { ICP-MS }\end{array}$ \\
\hline 1 & $\mathrm{Li}_{1.27} \mathrm{Ni}_{0.1} \mathrm{Mn}_{0.63} \mathrm{O}_{2}$ & $80: 20: 0$ & $0.864: 0.000: 0.136$ & $\mathrm{Li}_{1.269} \mathrm{Ni}_{0.096} \mathrm{Mn}_{0.635} \mathrm{O}_{2}$ \\
\hline 2 & $\mathrm{Li}_{1.23} \mathrm{Ni}_{0.14} \mathrm{Mn}_{0.61} \mathrm{Co}_{0.02} \mathrm{O}_{2}$ & $70: 25: 5$ & $0.793: 0.022: 0.185$ & $\mathrm{Li}_{1.227} \mathrm{Ni}_{0.152} \mathrm{Mn}_{0.616} \mathrm{Co}_{0.019} \mathrm{O}_{2}$ \\
\hline 3 & $\mathrm{Li}_{1.2} \mathrm{Ni}_{0.183} \mathrm{Mn}_{0.583} \mathrm{Co}_{0.04} \mathrm{O}_{2}$ & $60: 30: 10$ & $0.729: 0.042: 0.229$ & $\mathrm{Li}_{1.209} \mathrm{Ni}_{0.173} \mathrm{Mn}_{0.590} \mathrm{Co}_{0.028} \mathrm{O}_{2}$ \\
\hline 4 & $\mathrm{Li}_{1.17} \mathrm{Ni}_{0.22} \mathrm{Mn}_{0.56} \mathrm{Co}_{0.05} \mathrm{O}_{2}$ & $50: 35: 15$ & $0.670: 0.060: 0.270$ & $\mathrm{Li}_{1.168} \mathrm{Ni}_{0.223} \mathrm{Mn}_{0.559} \mathrm{Co}_{0.050} \mathrm{O}_{2}$ \\
\hline 5 & $\mathrm{Li}_{1.13} \mathrm{Ni}_{0.27} \mathrm{Mn}_{0.53} \mathrm{Co}_{0.07} \mathrm{O}_{2}$ & $40: 40: 20$ & $0.615: 0.077: 0.308$ & $\mathrm{Li}_{1.138} \mathrm{Ni}_{0.260} \mathrm{Mn}_{0.537} \mathrm{Co}_{0.065} \mathrm{O}_{2}$ \\
\hline 6 & $\mathrm{Li}_{1.1} \mathrm{Ni}_{0.31} \mathrm{Mn}_{0.51} \mathrm{Co}_{0.08} \mathrm{O}_{2}$ & $30: 45: 25$ & $0.565: 0.093: 0.343$ & $\mathrm{Li}_{1.10} \mathrm{Ni}_{0.310} \mathrm{Mn}_{0.510} \mathrm{Co}_{0.08} \mathrm{O}_{2}$ \\
\hline 7 & $\mathrm{Li}_{1.07} \mathrm{Ni}_{0.35} \mathrm{Mn}_{0.48} \mathrm{Co}_{0.1} \mathrm{O}_{2}$ & $20: 50: 30$ & $0.518: 0.107: 0.375$ & $\mathrm{Li}_{1.063} \mathrm{Ni}_{0.355} \mathrm{Mn}_{0.481} \mathrm{Co}_{0.101} \mathrm{O}_{2}$ \\
\hline 8 & $\mathrm{Li}_{1.03} \mathrm{Ni}_{0.39} \mathrm{Mn}_{0.46} \mathrm{Co}_{0.12} \mathrm{O}_{2}$ & $10: 55: 35$ & $0.474: 0.121: 0.405$ & $\mathrm{Li}_{1.03} \mathrm{Ni}_{0.39} \mathrm{Mn}_{0.46} \mathrm{Co}_{0.12} \mathrm{O}_{2}$ \\
\hline 9 & $\mathrm{LiNi}_{0.433} \mathrm{Mn}_{0.433} \mathrm{Co}_{0.133} \mathrm{O}_{2}$ & $0: 60: 40$ & $0.433: 0.133: 0.433$ & $\mathrm{LiNi}_{0.433} \mathrm{Mn}_{0.433} \mathrm{Co}_{0.133} \mathrm{O}_{2}$ \\
\hline 10 & $\mathrm{Li}_{1.2} \mathrm{Ni}_{0.2} \mathrm{Mn}_{0.6} \mathrm{O}_{2}$ & $60: 40: 0$ & $0.750: 0.000: 0.250$ & $\mathrm{Li}_{1.200} \mathrm{Ni}_{0.200} \mathrm{Mn}_{0.600} \mathrm{O}_{2}$ \\
\hline 11 & $\mathrm{Li}_{1.2} \mathrm{Ni}_{0.16} \mathrm{Mn}_{0.57} \mathrm{Co}_{0.07} \mathrm{O}_{2}$ & $60: 20: 20$ & $0.708: 0.083: 0.208$ & $\mathrm{Li}_{1.207} \mathrm{Ni}_{0.157} \mathrm{Mn}_{0.576} \mathrm{Co}_{0.065} \mathrm{O}_{2}$ \\
\hline 12 & $\mathrm{Li}_{1.2} \mathrm{Ni}_{0.15} \mathrm{Mn}_{0.55} \mathrm{Co}_{0.1} \mathrm{O}_{2}$ & $60: 10: 30$ & $0.688: 0.125: 0.188$ & $\mathrm{Li}_{1.203} \mathrm{Ni}_{0.149} \mathrm{Mn}_{0.550} \mathrm{Co}_{0.071} \mathrm{O}_{2}$ \\
\hline 13 & $\mathrm{Li}_{1.2} \mathrm{Ni}_{0.133} \mathrm{Mn}_{0.533} \mathrm{Co}_{0.133} \mathrm{O}_{2}$ & $60: 0: 40$ & $0.667: 0.167: 0.167$ & $\mathrm{Li}_{1.206} \mathrm{Ni}_{0.139} \mathrm{Mn}_{0.552} \mathrm{Co}_{0.103} \mathrm{O}_{2}$ \\
\hline 14 & $\mathrm{Li}_{1.27} \mathrm{Ni}_{0.1} \mathrm{Mn}_{0.63} \mathrm{O}_{2}$ & $80: 0: 20$ & $0.818: 0.091: 0.091$ & $\mathrm{Li}_{1.273} \mathrm{Ni}_{0.090} \mathrm{Mn}_{0.637} \mathrm{O}_{2}$ \\
\hline 15 & $\mathrm{Li}_{1.23} \mathrm{Ni}_{0.14} \mathrm{Mn}_{0.61} \mathrm{Co}_{0.02} \mathrm{O}_{2}$ & $70: 5: 25$ & $0.750: 0.109: 0.141$ & $\mathrm{Li}_{1.231} \mathrm{Ni}_{0.118} \mathrm{Mn}_{0.584} \mathrm{Co}_{0.083} \mathrm{O}_{2}$ \\
\hline 16 & $\mathrm{Li}_{1.17} \mathrm{Ni}_{0.22} \mathrm{Mn}_{0.56} \mathrm{Co}_{0.05} \mathrm{O}_{2}$ & $50: 15: 35$ & $0.630: 0.140: 0.2300$ & $\mathrm{Li}_{1.204} \mathrm{Ni}_{0.138} \mathrm{Mn}_{0.605} \mathrm{Co}_{0.053} \mathrm{O}_{2}$ \\
\hline 17 & $\mathrm{Li}_{1.2} \mathrm{Ni}_{0.27} \mathrm{Mn}_{0.53} \mathrm{Co}_{0.07} \mathrm{O}_{2}$ & $40: 20: 40$ & $0.577: 0.154: 0.269$ & $\mathrm{Li}_{1.132} \mathrm{Ni}_{0.235} \mathrm{Mn}_{0.499} \mathrm{Co}_{0.134} \mathrm{O}_{2}$ \\
\hline 18 & $\mathrm{Li}_{1.2} \mathrm{Ni}_{0.31} \mathrm{Mn}_{0.51} \mathrm{Co}_{0.08} \mathrm{O}_{2}$ & $30: 25: 45$ & $0.528: 0.167: 0.306$ & $\mathrm{Li}_{1.193} \mathrm{Ni}_{0.312} \mathrm{Mn}_{0.490} \mathrm{Co}_{0.05} \mathrm{O}_{2}$ \\
\hline 19 & $\mathrm{Li}_{1.07} \mathrm{Ni}_{0.35} \mathrm{Mn}_{0.48} \mathrm{Co}_{0.1} \mathrm{O}_{2}$ & $20: 30: 50$ & $0.482: 0.179: 0.339$ & $\mathrm{Li}_{1.065} \mathrm{Ni}_{0.318} \mathrm{Mn}_{0.449} \mathrm{Co}_{0.168} \mathrm{O}_{2}$ \\
\hline 20 & $\mathrm{Li}_{1.03} \mathrm{Ni}_{0.39} \mathrm{Mn}_{0.46} \mathrm{Co}_{0.12} \mathrm{O}_{2}$ & $10: 35: 55$ & $0.440: 0.190: 0.371$ & $\mathrm{Li}_{1.028} \mathrm{Ni}_{0.383} \mathrm{Mn}_{0.458} \mathrm{Co}_{0.131} \mathrm{O}_{2}$ \\
\hline 21 & $\mathrm{Li}_{1} \mathrm{Ni}_{0.43} \mathrm{Mn}_{0.43} \mathrm{Co}_{0.14} \mathrm{O}_{2}$ & $0: 40: 60$ & $0.400: 0.200: 0.400$ & $\mathrm{Li}_{1.05} \mathrm{Ni}_{0.428} \mathrm{Mn}_{0.430} \mathrm{Co}_{0.10} \mathrm{O}_{2}$ \\
\hline
\end{tabular}

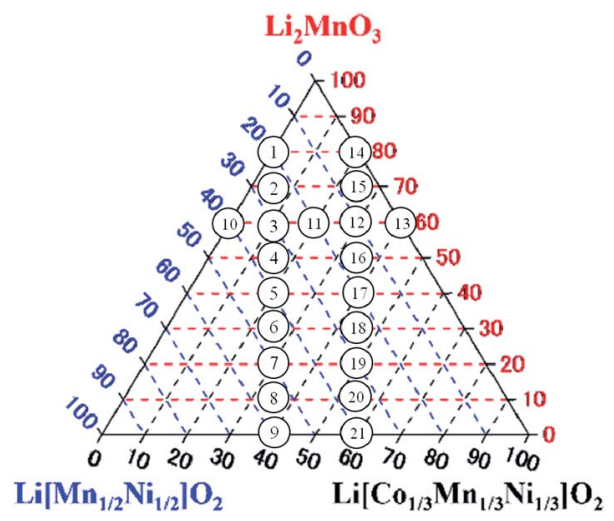

Fig. 1 Targeted compositions of synthesized LLO samples represented in the $\mathrm{Li}_{2} \mathrm{MnO}_{3}-\mathrm{LiNi}_{1 / 2} \mathrm{Mn}_{1 / 2} \mathrm{O}_{2}-\mathrm{LiNi}_{1 / 3} \mathrm{Mn}_{1 / 3} \mathrm{CO}_{1 / 3} \mathrm{O}_{2}$ ternary diagram. The numbers 1-21 in the circles indicate the sample number.

ratios in the synthesized cathode materials were measured to confirm the target ratios by ICP-MS using an Agilent 7700x spectrometer. The pXRD experiments were performed using $\mathrm{CuK}_{\alpha}$ radiation (Rigaku RINT-Ultima III; $\lambda=0.1548 \mathrm{~nm}$ ) at increments of 0.02 degrees over a range from 20 to 80 degrees. An obliquely finished Si crystal (non-reflection Si plate) was used as a sample holder to minimize the background. Brunauer-Emmett-Teller (BET) surface areas of the cathode particles were measured with a TriStar 3000 surface area instrument (Micromeritic Instrument Corporation). X-ray photoelectron spectroscopy (XPS) measurements (JP-9010 MC, JEOL) were performed to analyze the surface composition of the $\mathrm{Mn}$, Ni and Co ions in the samples prepared, and their bulk composition was analyzed with an X-ray fluorescence spectrometer (XRF, ZSX PrimusIV, Rigaku).
In order to investigate the oxidation states of the $\mathrm{Mn}, \mathrm{Ni}$ and Co ions of the LLO samples prepared with various compositions and cooling conditions, their X-ray absorption fine structures (XAFS) were analyzed using the BL01B1 beam line at the SPring8 facility (JASRI, Hyogo, Japan). The Mn, Co and Ni K-edge XAFS spectra were measured using quick XAFS (QXAFS) with transmission mode, and a double-crystal Si (111) monochromator was employed to obtain the XAFS data. The energy levels during the XAFS measurement were calibrated by the pre-edge peak in the spectrum of a $\mathrm{Cu}$ foil equal to $8980.3 \mathrm{eV}$. All XAFS spectra were analyzed using the program package Athena software. ${ }^{19}$

The SEM, XRD and Rietveld refinement analysis data shown in this paper were selected from samples 1, 3, 5, 9, 10 and 13 located in the vertical and horizon lines in the ternary diagram of Fig. 1 due to the space limitation in this paper, and because the comparison of the data obtained from samples 1, 3, 5, 9, 10 and 13 clearly indicates the conclusion of this study. The data of the other samples examined are shown and can be compared in the ESI. $\dagger$

\subsection{Cell preparation and electrochemical tests}

An accurately weighed quantity of $1 \mathrm{~g}$ of each LLO cathode material, $0.121 \mathrm{~g}$ of acetylene black (AB, DENKA BLACK, Denki Kagaku Kogyo Ltd., Japan) and $0.084 \mathrm{~g}$ of polyvinylidene difluoride (PVdF, KF polymer \#9130, $13 \mathrm{wt} \%$ in $N$-methyl-2-pyrrolidone (NMP), Kureha, Japan) were mixed in NMP (anhydrous 99.5\%, SigmaAldrich) using planetary mixing equipment (Mazerustar, KK250S, KURABO, Japan) to form a homogenous mixture. Each mixture (the solid content is $30-40 \mathrm{wt} \%$ ) had a suitable viscosity for coating it as the cathode film, while preserving the weight $\%$ of LLO $: A B: P V d F=83: 10: 7$ in the prepared cathode film. The mixture was coated using a doctor-blade coater (100 $\mu \mathrm{m}$ gap) on an aluminum (Al) current collector. The thin film mixture on the $\mathrm{Al}$ 
was dried at $130{ }^{\circ} \mathrm{C}$ for $5 \mathrm{~h}$ in a vacuum drying oven. The thusprepared electrodes were pressed with a roll press machine. The loading amount of each LLO on the Al current collector was 2.5$3.0 \mathrm{mg} \mathrm{cm}{ }^{-2}$. Each prepared cathode layer was kept at the loading density of $1.6 \mathrm{mg} \mathrm{cm}^{-3}$.

The cathode performance tests were performed using a CR2032 coin-type cell. The test cells were composed of a cathode and a lithium metal anode separated by a porous polypropylene film (Celgard 3401). The electrolyte used was a $1 \mathrm{M}$ lithium hexafluorophosphate $\left(\mathrm{LiPF}_{6}\right)$-ethylene carbonate (EC)/ dimethyl carbonate (DMC) mixture (1:2 by vol., Ube Chemicals, Japan). The charge/discharge cycling was performed using a multichannel battery tester (HJ1001SD8, Hokuto Denko Corporation, Japan). All tests were performed in a constant temperature bath (MIR-154, Panasonic) of $25{ }^{\circ} \mathrm{C}$. The constantcurrent/constant-voltage (CC-CV) mode was used for the cycling tests. The charge/discharge cycling tests after electrochemical pre-treatment process were performed at a charge/discharge current density of $0.1 \mathrm{C}$-rate. To observe the stable charge/ discharge cycle performance, the pre-treatment process developed by Ito et $a .^{\mathbf{2 0 , 2 1}}$ was applied in this study. The discharge voltage limit was fixed at $2.0 \mathrm{~V}$, and the charge voltage limit was increased by $0.1 \mathrm{~V}$ stepwise from 4.5 to $4.8 \mathrm{~V}$ every two cycles. The C-rate was calculated with the specific capacity of $200 \mathrm{~mA} \mathrm{~h} \mathrm{~g}^{-1}$ for all synthesized LLO materials. The cutoff voltages for the charging/discharging tests were 2.0 and $4.8 \mathrm{~V}$. During CV mode, the upper cutoff voltage was held constant for $5 \mathrm{~h}$.

\section{Results and discussion}

\subsection{Characterization of the synthesized LLO cathode materials and charging/discharging cycle tests of the LLO samples}

The synthesized LLO samples had the targeted compositions with an error of $15 \%$, which were evaluated with ICP-MS, as shown in Table 1, and the BET surface areas of $0.8-0.9 \mathrm{~m}^{2} \mathrm{~g}^{-1}$.
All secondary particles of the LLO samples were constructed with primary particles having the diameter of $100-200 \mathrm{~nm}$, as shown in Fig. 2 and S1. $\dagger$ From these results, the synthesized samples almost have the same morphology of particles between the quenched and slow cooling processes, and their compositions were changed systematically as we designed. In order to know the deviation of $\mathrm{Mn}, \mathrm{Ni}$ and Co ions in the sample particles, the surface and bulk compositions of the samples were analyzed with XPS and XRF, respectively (Table S1†). The bulk composition evaluated with XRF (Table S1†) was in good agreement with the targeted composition (Table 1) on each sample. In all samples irrespective of quenched and slow cooling processes, $\mathrm{Ni}$ atom is rich in the particle surface areas when compared with bulk. Conversely, the $\mathrm{Mn}$ atom is poor in the surface area when compared with the results of the bulk atomic and surface ratios in Table S1. $\dagger$ Although the surface composition of the Co atom is rich or poor in the sample surfaces, the reason why the trend of the composition of Co could not be observed is due to the low content of Co atom in the LLO samples. The degree of $\mathrm{Ni}$ richness in the particle surface increases a little when the slow cooling process was applied to the samples in comparison with one prepared using the quenched cooling process. The degree of Ni richness in the slow cooling process does not depend on the bulk composition. That means that the degree of difference in the composition between the surface and bulk areas was not caused by the difference of the cooling process applied when the samples were prepared.

Fig. 3 shows the (A) Mn, (B) Ni and (C) Co K-edge XANES spectra of sample 3 prepared by quenching the calcinated sample with liquid $\mathrm{N}_{2}$. Together with the spectra of sample 3, the spectra of the reference samples of $\mathrm{Mn}_{3} \mathrm{O}_{4}, \mathrm{Mn}_{2} \mathrm{O}_{3}, \mathrm{MnO}_{2}$, $\mathrm{NiO}, \mathrm{CoO}, \mathrm{LiCoO}_{2}$ are also shown in Fig. 3. Comparing the sample spectra with the reference spectra, the oxidation number of $\mathrm{Mn}$ ion in the sample 3 might be close to +4 because the sample spectra are similar to those of $\mathrm{MnO}_{2}$. From a similar

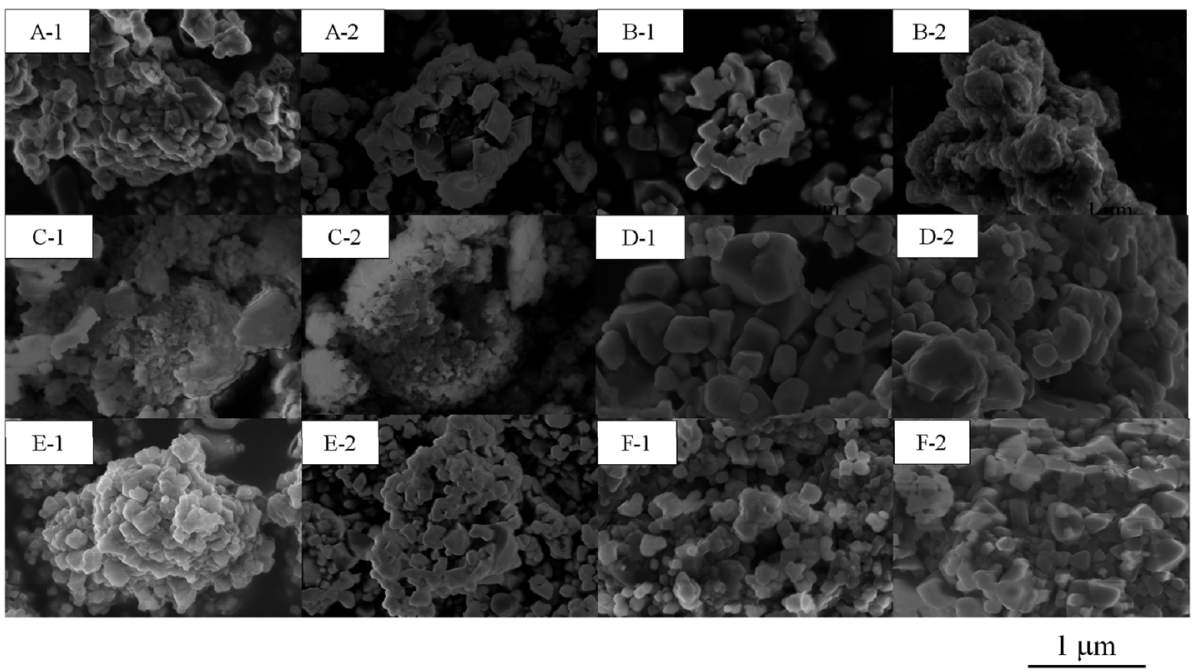

Fig. 2 SEM images of the LLO samples prepared by (A-1, B-1, C-1, D-1, E-1 and F-1) quenching the samples calcinated at $900{ }^{\circ} \mathrm{C}$ for $12 \mathrm{~h}$ in air with liquid nitrogen, and (A-2, B-2, C-2, D-2, E-2 and F-2) cooling them at a controlled cooling rate of $25^{\circ} \mathrm{Ch} \mathrm{h}^{-1}$ in the furnace from 900 to $25^{\circ} \mathrm{C}$. (A-1, A-2): sample 1, (B-1, B-2): sample 3, (C-1, C-2): sample 5, (D-1, D-2): sample 9, (E-1, E-2): sample 10 and (F-1, F-2): sample 13. 
point of view, the oxidation number of the Ni and Co ions might be +2 and +3 . These oxidation numbers of the $\mathrm{Mn}, \mathrm{Ni}$ and $\mathrm{Co}$ ions agree with ones reported in published papers. ${ }^{22-24}$ Fig. $\mathrm{S} 2 \dagger$ shows the difference in the K-edge XANES spectra of the Mn, Ni and Co ions between the samples 2-8 prepared by quenching the calcinated sample with liquid $\mathrm{N}_{2}$ (black line), and low cooling of the calcinated samples at the controlled rate of $25{ }^{\circ} \mathrm{C}$ $\mathrm{h}^{-1}$ (red line). As mentioned in Fig. 3, the slope of the K-edge XANES spectra depended on the oxidation states of the Mn, $\mathrm{Ni}$ and Co ions in the LLO samples. ${ }^{25}$ In the XANES spectra shown in Fig. $\mathrm{S} 2, \uparrow$ the difference (black vs. red lines) in the slopes of the XANES spectra observed with the samples prepared with the quenching and slow cooling processes could not be observed. The XANES spectra of the Co ions in the LLO samples exhibited a small difference between the spectra obtained with the samples prepared with quenching and slow cooling processes. The small difference in the spectra obtained with the samples prepared with the quenching and slow cooling processes is due to the low content of Co ion. These results indicate that the average oxidation states of the $\mathrm{Mn}, \mathrm{Ni}$ and $\mathrm{Co}$ ions in the LLO samples are not affected by changing the cooling process. From all results shown above, the surface morphology, surface composition and the electronic state of ions in the samples are not the factors that exhibit a difference in the discharge capacity of the LLO samples prepared with quenched and slow cooling processes. The difference in the crystal structure of the LLO samples prepared with quenched and slow cooling processes, as shown below, can be discussed to elucidate the effect of the cooling process on the cathode performance.
Fig. 4 shows the charging/discharging voltage-capacity curves observed at the $10^{\text {th }}$ cycle with the samples $1,3,5,9,10$, 13, 14, 17 and 21. The charging/discharging voltage-capacity curves for the other samples are shown in Fig. S3. $\dagger$ In all samples, the charging/discharging voltage-capacity curves exhibited characteristic large voltage hysteresis during the charging and discharging processes, although the conventional $\mathrm{LiCoO}_{2}$ and $\mathrm{LiNi}_{1 / 3} \mathrm{Mn}_{1 / 3} \mathrm{Co}_{1 / 3} \mathrm{O}_{2}$ cathode materials exhibited almost constant voltages in both charging and discharging processes. $^{26}$ The difference in the shape of the charging/ discharging voltage-capacity curves between the samples prepared by quenched and slow cooling processes could not be observed in all LLO samples tested. Depending on the composition of the LLO samples, the observed capacities and the magnitude of the retention of charge/discharge capacities observed were changed. This means that in some compositions, the quenched cooling process was effective for observing the higher capacity. In other compositions, the LLO samples prepared with the slow cooling process exhibited higher capacity. In Fig. $\mathrm{S} 4, \uparrow \mathrm{d} Q / \mathrm{d} V$ curves calculated with the charging/ discharging capacity $v s$. voltage curves at the $10^{\text {th }}$ cycle are shown. Generally, the difference in the $\mathrm{d} Q / \mathrm{d} V$ curves between the samples prepared by quenched and slow cooling processes could be observed in the area where the $\mathrm{Li}_{2} \mathrm{MnO}_{3}$ percentages in the samples are high (samples 1, 2, 3 and 14 and 15) and low (samples 8, 9, 20 and 21). However, the difference in the $\mathrm{d} Q / \mathrm{d} V$ curves could not be observed in the area (samples 4, 5, 6, 7, 12, 16, 17 and 18) where the difference in the charging/discharging capacities between the samples prepared by quenching and slow cooling processes could be observed (around $60 \% \mathrm{Li}_{2} \mathrm{MnO}_{3}$ composition). Therefore, the difference in the cooling process
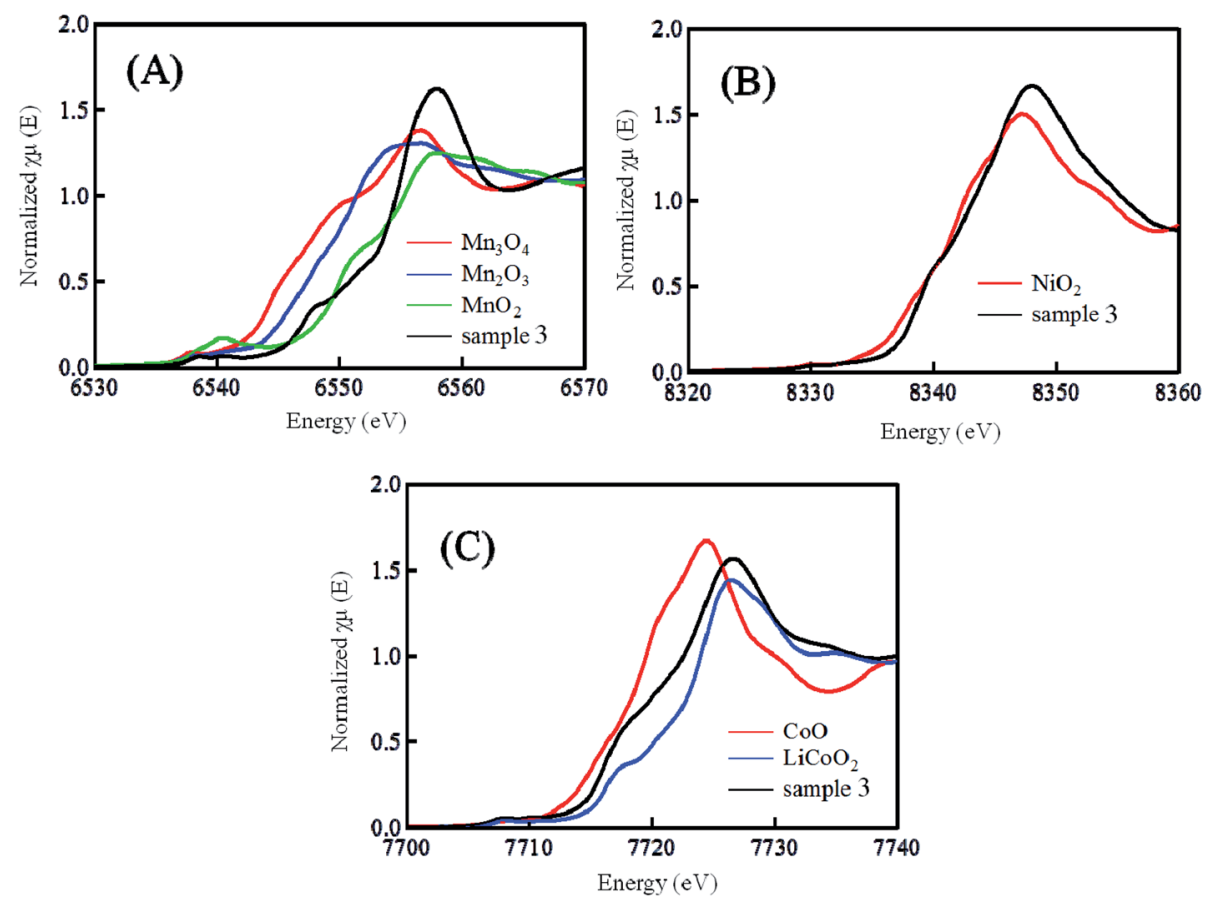

Fig. 3 (A) Mn, (B) Ni and (C) Co K-edge XANES spectra of sample 3 prepared by the quenched cooling with liquid nitrogen and reference samples of $\mathrm{Mn}_{3} \mathrm{O}_{4}, \mathrm{Mn}_{2} \mathrm{O}_{3}, \mathrm{MnO}, \mathrm{NiO}_{2}, \mathrm{CoO}$ and $\mathrm{LiCoO}_{2}$. 

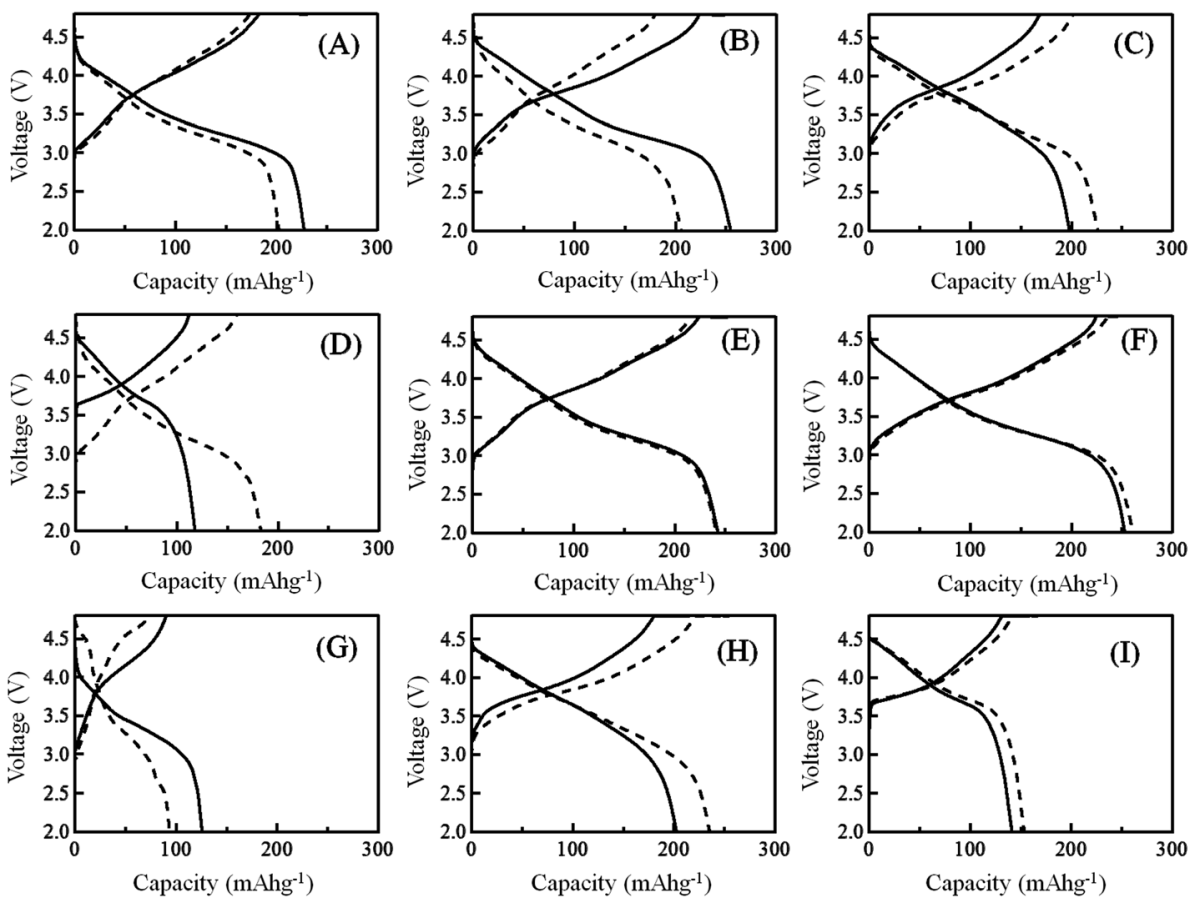

Fig. 4 Charging/discharging voltage-capacity curves obtained at the 10 $0^{\text {th }}$ cycle with samples 1 (A), 3 (B), 5 (C), 9 (D), 10 (E), 13 (F), 14 (G), 17 (H) and 21 (I) prepared by the quenched cooling with liquid nitrogen (solid lines), and the slow cooling in the furnace at a controlled rate of $25{ }^{\circ} \mathrm{C} \mathrm{h}^{-1}$ (dotted lines). The charging/discharging rate was $0.1 \mathrm{C}$.

Table 2 Summary of the discharge capacity of LLO samples (no. 1-21) at the $10^{\text {th }}$ cycle. The samples were prepared by quenching the samples calcinated at $900{ }^{\circ} \mathrm{C}$ for $12 \mathrm{~h}$ in air with liquid nitrogen ("quenched cooling"), and cooling them at a controlled cooling rate of $25^{\circ} \mathrm{C} \mathrm{h}^{-1}$ in the furnace from 900 to $25^{\circ} \mathrm{C}$ ("slow cooling"). The discharging rate was $0.1 \mathrm{C}$

\begin{tabular}{lll}
\hline & \multicolumn{2}{l}{ Discharge capacity $\left(\mathrm{mA} \mathrm{h} \mathrm{g}^{-1}\right)$} \\
\cline { 2 - 3 } Sample no. & Quenched cooling & Slow cooling \\
\hline 1 & 227 & 203 \\
2 & 286 & 232 \\
3 & 260 & 205 \\
4 & 234 & 236 \\
5 & 198 & 226 \\
6 & 150 & 170 \\
7 & 167 & 181 \\
8 & 197 & 211 \\
9 & 172 & 183 \\
10 & 233 & 241 \\
11 & 264 & 242 \\
12 & 254 & 236 \\
13 & 253 & 261 \\
14 & 133 & 102 \\
15 & 176 & 150 \\
16 & 188 & 204 \\
17 & 200 & 234 \\
18 & 186 & 201 \\
19 & 153 & 169 \\
20 & 168 & 186 \\
21 & 141 & 154 \\
& &
\end{tabular}

does not influence the redox potentials of the $\mathrm{Mn}, \mathrm{Ni}$ and $\mathrm{Co}$ ions in the LLO samples. Fig. S5 $\uparrow$ shows the results of the charging/discharging cycle performance tests obtained at 0.1C. Until the $6^{\text {th }}$ cycle, the pre-treatment explained in the experimental section was applied to all cathodes. From the $7^{\text {th }}$ cycle, the charging/discharging cycle tests were started between the cutoff voltages of 4.8 and $2.0 \mathrm{~V}$. The discharge capacities at the $10^{\text {th }}$ cycle are summarized in Table 2 . In the LLO samples 3,11 , 12, 13 that contained the $\mathrm{Li}_{2} \mathrm{MnO}_{3}$ component with high percentage and exhibited higher discharge capacities in the quenched samples, the discharge capacity decreased with increasing cycle number even though the samples exhibited high discharge capacity. These results indicate that the samples exhibiting high discharge capacity do not always exhibit high cycle durability, and that improvement of the cycle durability of the LLO samples cannot be achieved by selecting the cooling process after calcination of the LLO samples. From Table 2, the difference in the discharge capacities observed at the $10^{\text {th }}$ cycle with the samples prepared by quenched and slow cooling processes was calculated, and their difference in the composition of LLO is summarized in Fig. 5. In Fig. 5, the colored circles show the degree of the difference in the discharge capacities between the quenched and slow cooling samples. The difference in the discharge capacities is defined as follows:

Difference of the discharge capacity $=\{$ (discharge capacity of the LLO sample prepared by quenching) - (discharge capacity of the LLO sample prepared by slow cooling) $\}$ at the $10^{\text {th }}$ discharge cycle 


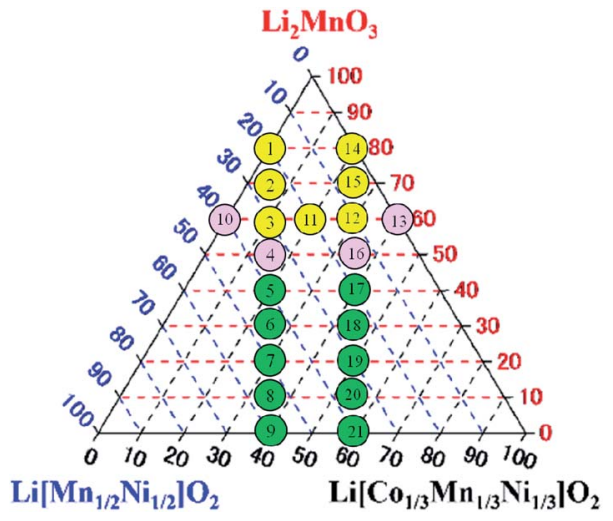

Fig. 5 Summary of the dependence of the difference in discharge capacity obtained at the $10^{\text {th }}$ cycle on the targeted composition of the LLO samples. The difference in discharge capacity = (discharge capacity of the LLO sample prepared by the quenched cooling) (discharge capacity of the LLO sample prepared by slow cooling). The difference in discharge capacities: $>10 \mathrm{~mA} \mathrm{~h} \mathrm{~g}^{-1},-10 \mathrm{~mA} \mathrm{~h} \mathrm{~g}^{-1}<<$ $10 \mathrm{~mA} \mathrm{~h} \mathrm{~g}^{-1},<-10 \mathrm{~mA} \mathrm{~h} \mathrm{~g}^{-1}$.

The LLO samples prepared by quenching in the yellow colored circles exhibited higher discharge capacity than those prepared by slow cooling. The samples in the pink area, which adjoined the yellow area, showed that the discharge capacities of the samples prepared with quenching and slow cooling did not have a large difference. In the green circles, the slow cooling process was effective for the samples to display higher discharge capacity. A clear classification of the composition could be observed for the question of which cooling process was effective to observe higher discharge capacity.

\subsection{Evaluation of the difference of the crystal structure of the LLO samples after quenching and slow cooling processes with pXDR and Rietveld refinement analysis}

In order to elucidate the difference of the crystal structure of the LLO samples prepared with the two types of cooling processes, pXRD patterns of the LLO samples prepared with the two types of cooling processes were obtained. Typical pXRD patterns of samples 1, 3, 5, 9, 10 and 13 are shown in Fig. 6-8, and other results are shown in Fig. S6. $\dagger$ The pXRD Rietveld refinement profiles of the LLO samples are also shown as calculated profiles and the residual difference in Fig. 6-8 and S6. $\dagger$

In Table 3 and $S 2, \dagger$ the refined structural parameters of the LLO samples obtained from the Rietveld refinement ${ }^{21,27}$ with the space group of $C 2 / \mathrm{m}$ are summarized. The comparison of the structural parameters obtained is summarized in Table 4. The definition of the colors used in Table 4 is the same as those used for the difference in the discharge capacity between the samples prepared by quenching and slow cooling in Fig. 5. In all XRD patterns, the peaks at around $20-25^{\circ}$ that result from the ordering of $\mathrm{Li}^{+}$ions in the transition metal layers could be observed. ${ }^{28}$ Considering the composition of samples 9 and 21, the samples do not contain the component of $\mathrm{Li}_{2} \mathrm{MnO}_{3}$. Therefore, the sample should have a layered $\alpha-\mathrm{NaFeO}_{2}$-type rock

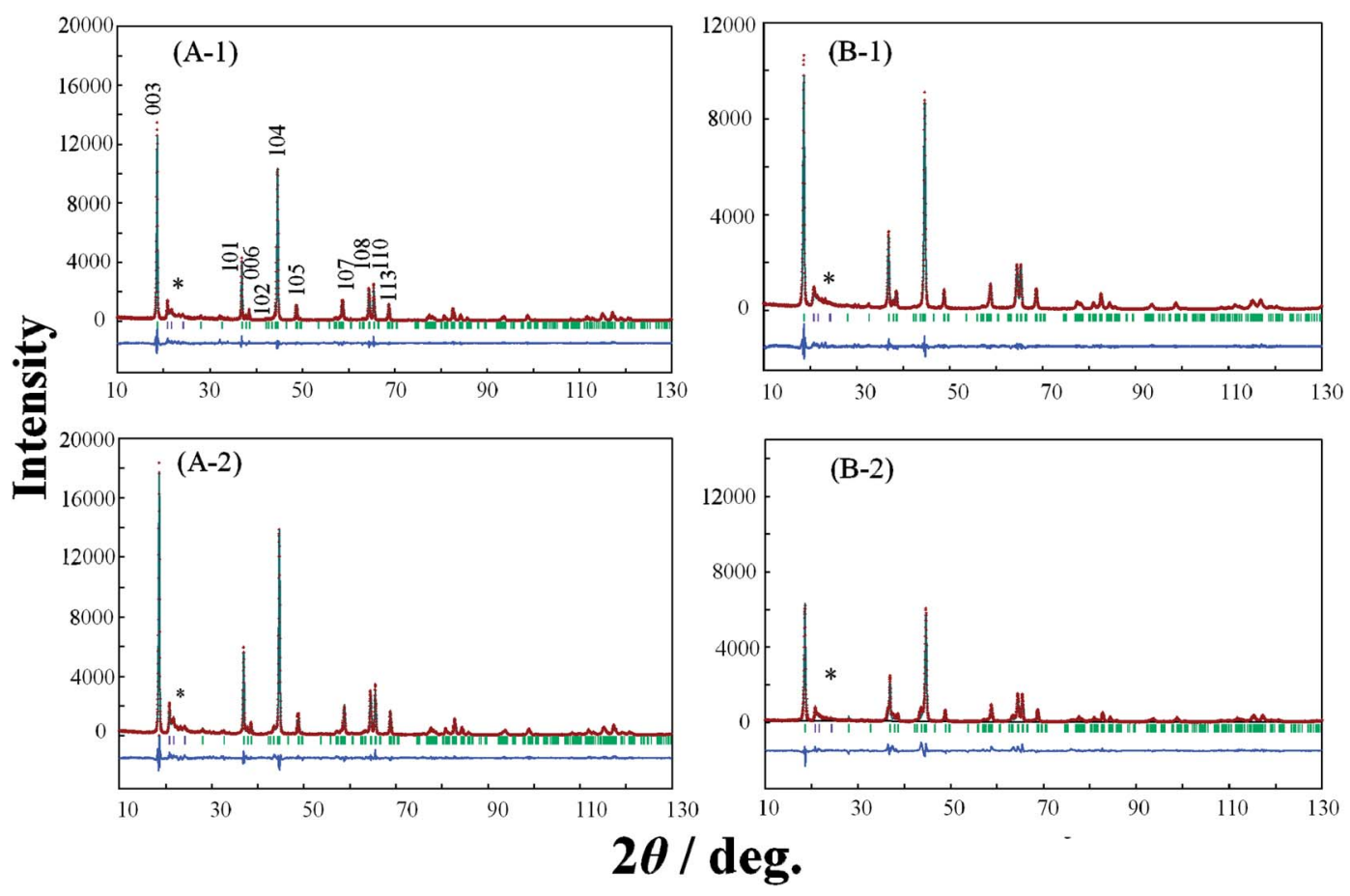

Fig. 6 XRD Rietveld refinement profiles of samples $1(A-1, A-2)$ and $3(B-1, B-2)$ prepared by $(A-1, B-1)$ the quenched cooling with liquid nitrogen, and $(A-2, B-2)$ the slow cooling in the furnace at a controlled rate of $25^{\circ} \mathrm{Ch}^{-1}$. (-) observed, (-) calculated, (-) the difference of both. The green vertical marks indicate the position of the Bragg reflections. * corresponds to the peaks around $20-25^{\circ}$ that result from the ordering of $\mathrm{Li}^{+}$ions in the transition metal layers. 


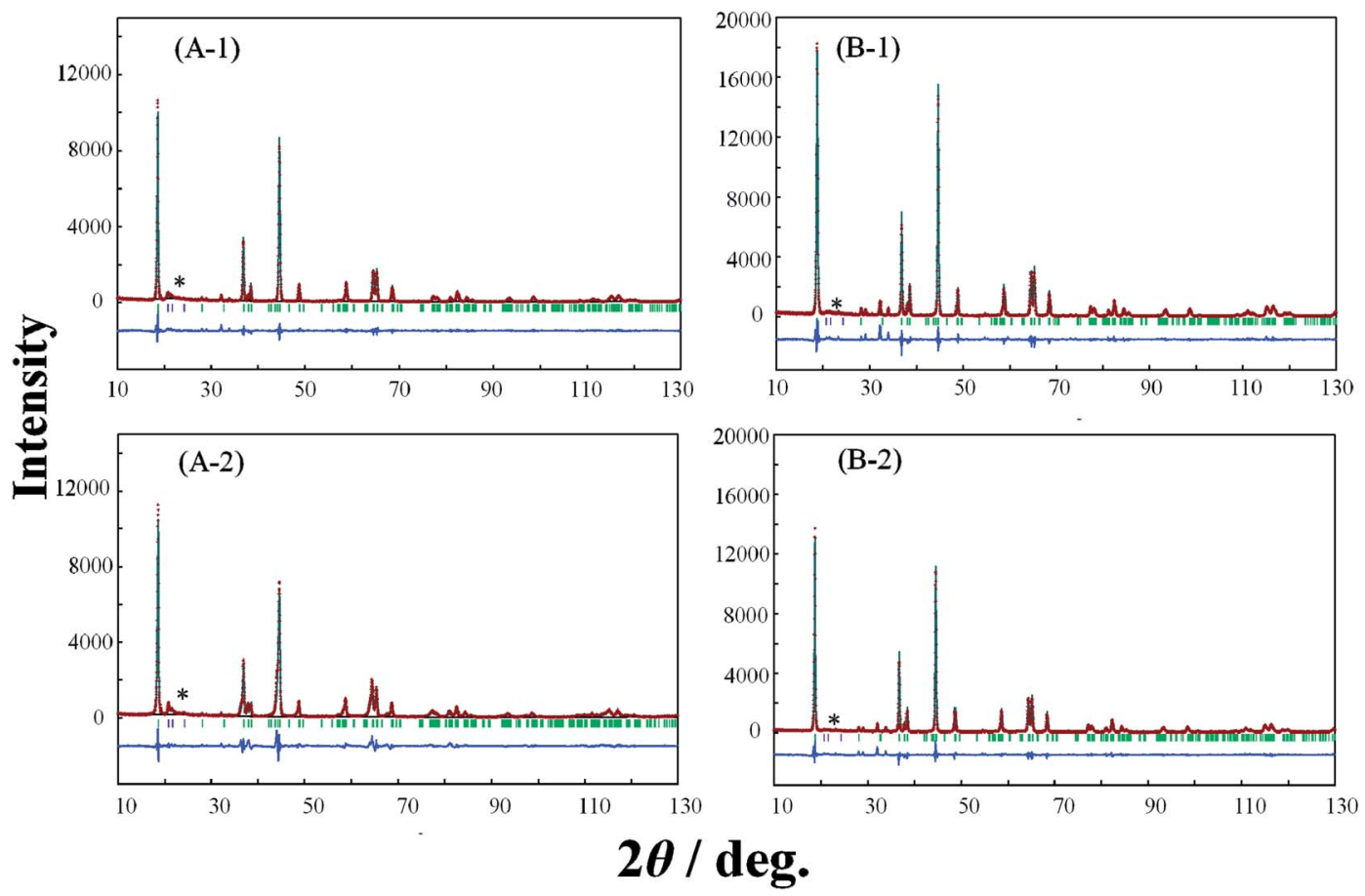

Fig. 7 XRD Rietveld refinement profiles of samples $5(A-1, A-2)$ and $9(B-1, B-2)$ prepared by $(A-1, B-1)$ the quenched cooling with liquid nitrogen, and $(A-2, B-2)$ the slow cooling in the furnace at a controlled rate of $25^{\circ} \mathrm{C} \mathrm{h}^{-1}$. (-) observed, (-) calculated, $(-)$ the difference of both. The green vertical marks indicate the position of the Bragg reflections. * corresponds to the peaks around $20-25^{\circ}$ that result from the ordering of $\mathrm{Li}^{+}$ions in the transition metal layers.

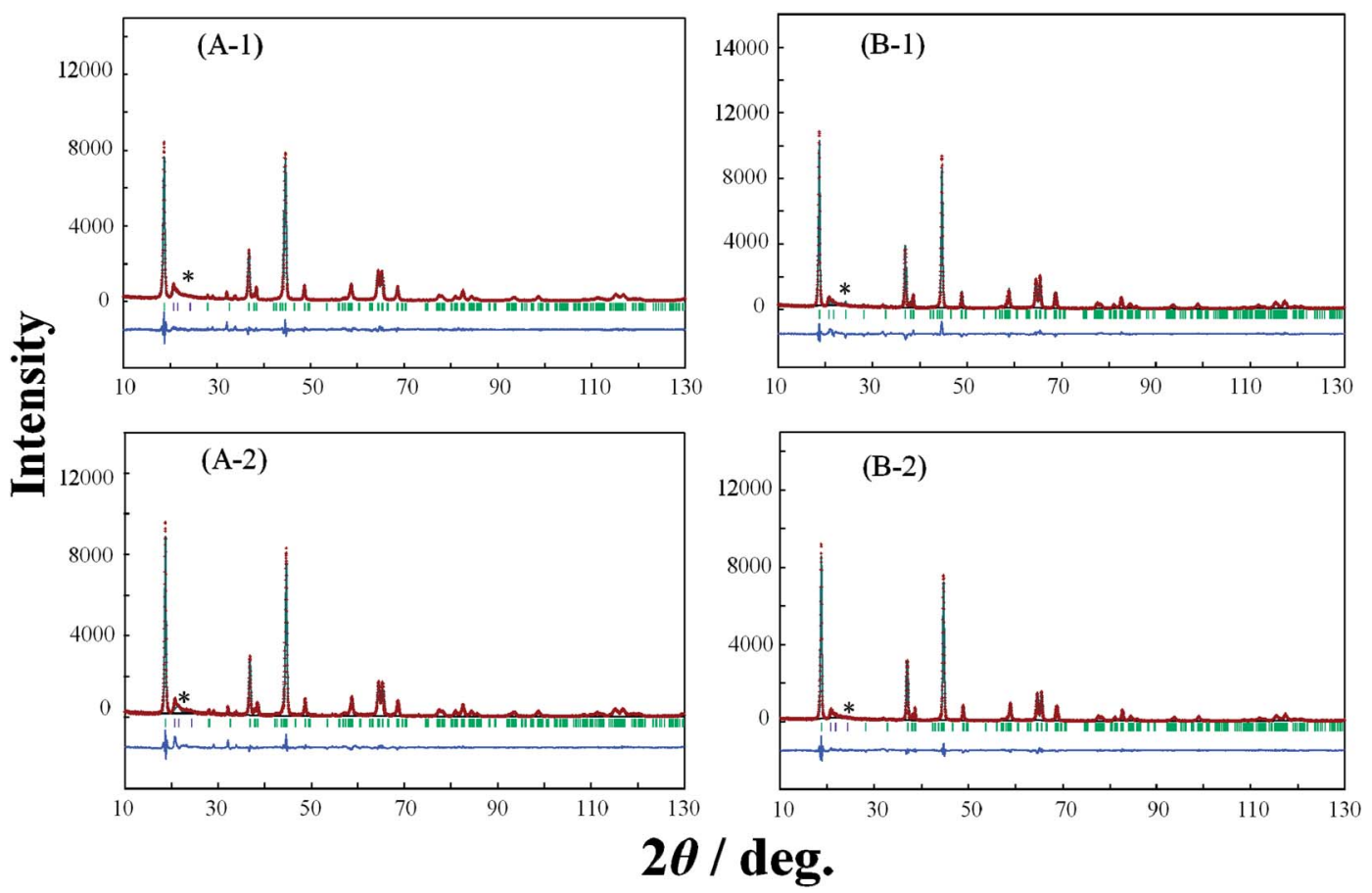

Fig. 8 XRD Rietveld refinement profiles of samples $10(A-1, A-2)$ and $13(B-1, B-2)$ prepared by (A-1, B-1) the quenched cooling with liquid nitrogen, and (A-2, B-2) slow cooling in the furnace at a controlled rate of $25^{\circ} \mathrm{C} \mathrm{h}^{-1}$. (-) observed, (-) calculated, $(-)$ the residual difference of both. The green vertical marks indicate the position of the Bragg reflections. * corresponds to the peaks around $20-25^{\circ}$ that result from the ordering of $\mathrm{Li}^{+}$ions in the transition metal layers. 
Table 3 The refined structural parameters of LLO samples obtained from the Rietveld refinement with the space of $\mathrm{C} 2 / \mathrm{m}$. The LLO samples were prepared by (1) the quenched cooling with liquid nitrogen, and (2) the slow cooling in the furnace at a controlled rate of $25^{\circ} \mathrm{C} \mathrm{h}^{-1}$. Samples: 1 (A), 3 (B), 5 (C), 9 (D), 10 (E) and 13 (F)

(A-1)

$S=1.9821, R_{\mathrm{B}}=4.383, R_{\mathrm{F}}=3.712, R_{\mathrm{wp}}=13.511$

\begin{tabular}{|c|c|c|c|c|c|}
\hline Atom & Site & $x$ & $y$ & $z$ & Occ $_{\text {-refined }}$ \\
\hline $\mathrm{Li}$ & $2 \mathrm{c}$ & 0 & 0 & 0.5 & $0.975(2)$ \\
\hline M & $2 c$ & 0 & 0 & 0.5 & $0.025(2)$ \\
\hline $\mathrm{Li}$ & $2 b$ & 0 & 0.5 & 0 & $0.748(6)$ \\
\hline M & $2 b$ & 0 & 0.5 & 0 & $0.252(6)$ \\
\hline $\mathrm{Li}$ & $4 g$ & 0 & $0.1646(3)$ & 0 & $0.040(6)$ \\
\hline M & $4 g$ & 0 & $0.1646(3)$ & 0 & $0.960(6)$ \\
\hline $\mathrm{Li}$ & $4 \mathrm{~h}$ & 0 & $0.681(2)$ & 0.5 & $0.996(1)$ \\
\hline M & $4 \mathrm{~h}$ & 0 & $0.681(2)$ & 0.5 & $0.004(1)$ \\
\hline $\mathrm{O}$ & $4 \mathrm{i}$ & $0.213(2)$ & 0 & $0.2169(9)$ & 1 \\
\hline $\mathrm{O}$ & $8 \mathrm{j}$ & $0.257(1)$ & $0.3151(6)$ & $0.2270(6)$ & 1 \\
\hline
\end{tabular}

\begin{tabular}{|c|c|c|c|c|c|}
\hline \multicolumn{6}{|c|}{$S=2.0339, R_{\mathrm{B}}=6.018, R_{\mathrm{F}}=5.440, R_{\mathrm{wp}}=12.940$} \\
\hline \multicolumn{6}{|c|}{$a=4.9341(3) \AA, b=8.5419(3) \AA, c=5.0343(2) \AA, \beta=109.202(4)^{\circ}$} \\
\hline Atom & Site & $x$ & $y$ & $z$ & Occ $_{\text {-refined }}$ \\
\hline $\mathrm{Li}$ & $2 c$ & 0 & 0 & 0.5 & $0.954(3)$ \\
\hline M & $2 c$ & 0 & 0 & 0.5 & $0.046(3)$ \\
\hline $\mathrm{Li}$ & $2 b$ & 0 & 0.5 & 0 & $0.546(5)$ \\
\hline M & $2 b$ & 0 & 0.5 & 0 & $0.454(5)$ \\
\hline $\mathrm{Li}$ & $4 \mathrm{~g}$ & 0 & $0.1697(3)$ & 0 & $0.054(5)$ \\
\hline M & $4 \mathrm{~g}$ & 0 & $0.1697(3)$ & 0 & $0.946(5)$ \\
\hline $\mathrm{Li}$ & $4 \mathrm{~h}$ & 0 & $0.699(2)$ & 0.5 & $0.998(2)$ \\
\hline M & $4 \mathrm{~h}$ & 0 & $0.699(2)$ & 0.5 & $0.002(2)$ \\
\hline $\mathrm{O}$ & $4 \mathrm{i}$ & $0.208(1)$ & 0 & $0.220(1)$ & 1 \\
\hline $\mathrm{O}$ & $8 \mathrm{j}$ & $0.261(1)$ & $0.3209(7)$ & $0.2195(7)$ & 1 \\
\hline
\end{tabular}

(B-1)

$\underline{S=1.7132, R_{\mathrm{B}}=4.117, R_{\mathrm{F}}=3.246, R_{\mathrm{wp}}=11.975}$

\begin{tabular}{llllll}
\multicolumn{5}{l}{$a=4.9502(5) \AA}$, \\
\hline Atom & Site & $x$ & $y$ & $z$ & Occ-refined \\
\hline $\mathrm{Li}$ & $2 \mathrm{c}$ & 0 & 0 & 0.5 & $0.982(2)$ \\
$\mathrm{M}$ & $2 \mathrm{c}$ & 0 & 0 & 0.5 & $0.018(2)$ \\
$\mathrm{Li}$ & $2 \mathrm{~b}$ & 0 & 0.5 & 0 & $0.605(5)$ \\
$\mathrm{M}$ & $2 \mathrm{~b}$ & 0 & 0.5 & 0 & $0.395(5)$ \\
$\mathrm{Li}$ & $4 \mathrm{~g}$ & 0 & $0.1642(2)$ & 0 & $0.031(5)$ \\
$\mathrm{M}$ & $4 \mathrm{~g}$ & 0 & $0.1624(2)$ & 0 & $0.969(5)$ \\
$\mathrm{Li}$ & $4 \mathrm{~h}$ & 0 & $0.681(1)$ & 0.5 & $0.978(1)$ \\
$\mathrm{M}$ & $4 \mathrm{~h}$ & 0 & $0.681(1)$ & 0.5 & $0.022(1)$ \\
$\mathrm{O}$ & $4 \mathrm{i}$ & $0.217(2)$ & 0 & $0.213(1)$ & 1 \\
$\mathrm{O}$ & $8 \mathrm{j}$ & $0.263(1)$ & $0.3154(6)$ & $0.2303(7)$ & 1
\end{tabular}

Table 3 (Contd.)

(B-2)

$S=2.5756, R_{\mathrm{B}}=11.247, R_{\mathrm{F}}=7.649, R_{\mathrm{wp}}=19.371$

$a=4.93366(5) \AA, \quad b=8.54179(6) \AA, c=5.02738(3) \AA, \beta=109.18(7)^{\circ}$

\begin{tabular}{llllll} 
Atom & Site & $x$ & $y$ & $z$ & Occ-refined \\
\hline $\mathrm{Li}$ & $2 \mathrm{c}$ & 0 & 0 & 0.5 & $0.946(5)$ \\
$\mathrm{M}$ & $2 \mathrm{c}$ & 0 & 0 & 0.5 & $0.054(5)$ \\
$\mathrm{Li}$ & $2 \mathrm{~b}$ & 0 & 0.5 & 0 & $0.596(5)$ \\
$\mathrm{M}$ & $2 \mathrm{~b}$ & 0 & 0.5 & 0 & $0.404(5)$ \\
$\mathrm{Li}$ & $4 \mathrm{~g}$ & 0 & $0.1642(2)$ & 0 & $0.059(5)$ \\
$\mathrm{M}$ & $4 \mathrm{~g}$ & 0 & $0.1624(2)$ & 0 & $0.941(7)$ \\
$\mathrm{Li}$ & $4 \mathrm{~h}$ & 0 & $0.681(1)$ & 0.5 & $0.970(3)$ \\
$\mathrm{M}$ & $4 \mathrm{~h}$ & 0 & $0.681(1)$ & 0.5 & $0.030(1)$ \\
$\mathrm{O}$ & $4 \mathrm{i}$ & $0.216(1)$ & 0 & $0.220(1)$ & 1 \\
$\mathrm{O}$ & $8 \mathrm{j}$ & $0.265(2)$ & $0.3327(7)$ & $0.2250(7)$ & 1 \\
\hline
\end{tabular}

(C-1)

$\underline{S=1.8172, R_{\mathrm{B}}=4.806, R_{\mathrm{F}}=5.012, R_{\mathrm{wp}}=13.040}$

$a=4.95601(2) \AA, b=8.5612(3) \AA, c=5.0164(1) \AA, \beta=109.109(4)^{\circ}$

\begin{tabular}{llllll} 
Atom & Site & $x$ & $y$ & $z$ & Occ $_{\text {-refined }}$ \\
\hline $\mathrm{Li}$ & $2 \mathrm{c}$ & 0 & 0 & 0.5 & $0.950(8)$ \\
$\mathrm{M}$ & $2 \mathrm{c}$ & 0 & 0 & 0.5 & $0.050(8)$ \\
$\mathrm{Li}$ & $2 \mathrm{~b}$ & 0 & 0.5 & 0 & $0.349(6)$ \\
$\mathrm{M}$ & $2 \mathrm{~b}$ & 0 & 0.5 & 0 & $0.651(6)$ \\
$\mathrm{Li}$ & $4 \mathrm{~g}$ & 0 & $0.1646(3)$ & 0 & $0.098(6)$ \\
$\mathrm{M}$ & $4 \mathrm{~g}$ & 0 & $0.1646(3)$ & 0 & $0.902(6)$ \\
$\mathrm{Li}$ & $4 \mathrm{~h}$ & 0 & $0.681(1)$ & 0.5 & $0.973(4)$ \\
$\mathrm{M}$ & $4 \mathrm{~h}$ & 0 & $0.681(1)$ & 0.5 & $0.027(4)$ \\
$\mathrm{O}$ & $4 \mathrm{i}$ & $0.215(2)$ & 0 & $0.221(2)$ & 1 \\
$\mathrm{O}$ & $8 \mathrm{j}$ & $0.269(2)$ & $0.3152(6)$ & $0.227(1)$ & 1 \\
\hline
\end{tabular}

(C-2)

$S=2.0646, R_{\mathrm{B}}=4.020, R_{\mathrm{F}}=2.430, R_{\mathrm{wp}}=15.57$

$a=4.9300(3) \AA, b=8.5641(3) \AA, c=5.0221(4) \AA, \beta=109.060(6)^{\circ}$

\begin{tabular}{llllll} 
Atom & Site & $x$ & $y$ & $z$ & Occ-refined \\
\hline $\mathrm{Li}$ & $2 \mathrm{c}$ & 0 & 0 & 0.5 & $0.958(8)$ \\
$\mathrm{M}$ & $2 \mathrm{c}$ & 0 & 0 & 0.5 & $0.042(8)$ \\
$\mathrm{Li}$ & $2 \mathrm{~b}$ & 0 & 0.5 & 0 & $0.474(7)$ \\
$\mathrm{M}$ & $2 \mathrm{~b}$ & 0 & 0.5 & 0 & $0.526(7)$ \\
$\mathrm{Li}$ & $4 \mathrm{~g}$ & 0 & $0.163(4)$ & 0 & $0.076(7)$ \\
$\mathrm{M}$ & $4 \mathrm{~g}$ & 0 & $0.163(4)$ & 0 & $0.924(8)$ \\
$\mathrm{Li}$ & $4 \mathrm{~h}$ & 0 & $0.692(1)$ & 0.5 & $0.970(4)$ \\
$\mathrm{M}$ & $4 \mathrm{~h}$ & 0 & $0.692(1)$ & 0.5 & $0.030(4)$ \\
$\mathrm{O}$ & $4 \mathrm{i}$ & $0.233(2)$ & 0 & $0.216(2)$ & 1 \\
$\mathrm{O}$ & $8 \mathrm{j}$ & $0.252(3)$ & $0.320(1)$ & $0.228(1)$ & 1
\end{tabular}


Table 3 (Contd.)

\begin{tabular}{|c|c|c|c|c|c|}
\hline$S=2.2$ & $23, R_{\mathrm{B}}$ & $5.329, R_{\mathrm{F}}=$ & $797, R_{\mathrm{wp}}=$ & 826 & \\
\hline$a=4.5$ & $0(2) \AA$ & $=8.5800(3$ & $c=5.015$ & $\AA$ & $0(2)^{\circ}$ \\
\hline Atom & Site & $x$ & $y$ & $z$ & Occ $_{\text {-refined }}$ \\
\hline $\mathrm{Li}$ & $2 \mathrm{c}$ & 0 & 0 & 0.5 & $0.901(7)$ \\
\hline $\mathbf{M}$ & $2 c$ & 0 & 0 & 0.5 & $0.099(7)$ \\
\hline $\mathrm{Li}$ & $2 b$ & 0 & 0.5 & 0 & $0.013(9)$ \\
\hline M & $2 b$ & 0 & 0.5 & 0 & $0.997(9)$ \\
\hline $\mathrm{Li}$ & $4 g$ & 0 & $0.1667(6)$ & 0 & $0.111(9)$ \\
\hline M & $4 g$ & 0 & $0.1667(6)$ & 0 & $0.889(9)$ \\
\hline $\mathrm{Li}$ & $4 \mathrm{~h}$ & 0 & $0.676(3)$ & 0.5 & $0.980(7)$ \\
\hline $\mathbf{M}$ & $4 \mathrm{~h}$ & 0 & $0.676(3)$ & 0.5 & $0.020(7)$ \\
\hline $\mathrm{O}$ & $4 \mathrm{i}$ & $0.237(3)$ & 0 & $0.213(2)$ & 1 \\
\hline $\mathrm{O}$ & $8 \mathrm{j}$ & $0.232(3)$ & $0.341(1)$ & $0.229(1)$ & 1 \\
\hline
\end{tabular}

(D-2)

\begin{tabular}{|c|c|c|c|c|c|}
\hline \multicolumn{6}{|c|}{$a=4.9546(2) \AA, b=8.5868(2) \AA, c=5.0164(1) \AA, \beta=109.129(3)^{\circ}$} \\
\hline Atom & Site & $x$ & $y$ & $z$ & Occ $_{\text {-refine }}$ \\
\hline $\mathrm{Li}$ & $2 c$ & 0 & 0 & 0.5 & $0.912(6)$ \\
\hline M & $2 c$ & 0 & 0 & 0.5 & $0.088(6)$ \\
\hline $\mathrm{Li}$ & $2 b$ & 0 & 0.5 & 0 & $0.007(6)$ \\
\hline M & $2 \mathrm{~b}$ & 0 & 0.5 & 0 & $0.993(6)$ \\
\hline $\mathrm{Li}$ & $4 \mathrm{~g}$ & 0 & $0.1631(7)$ & 0 & $0.092(6)$ \\
\hline M & $4 \mathrm{~g}$ & 0 & $0.1631(7)$ & 0 & $0.908(6)$ \\
\hline $\mathrm{Li}$ & $4 \mathrm{~h}$ & 0 & $0.670(3)$ & 0.5 & $0.993(3)$ \\
\hline M & $4 \mathrm{~h}$ & 0 & $0.670(3)$ & 0.5 & $0.007(3)$ \\
\hline $\mathrm{O}$ & $4 \mathrm{i}$ & $0.231(2)$ & 0 & $0.215(3)$ & 1 \\
\hline $\mathrm{O}$ & $8 \mathbf{j}$ & $0.240(2)$ & $0.3313(9)$ & $0.236(2)$ & 1 \\
\hline
\end{tabular}

(E-1)

$S=2.0025, R_{\mathrm{B}}=3.911, R_{\mathrm{F}}=3.000, R_{\mathrm{wp}}=13.149$

$a=4.9556(8) \AA, b=8.5618(9) \AA$, $c=5.0235(5) \AA, \beta=109.09(1)^{\circ}$

\begin{tabular}{llllll} 
Atom & Site & $x$ & $y$ & $z$ & Occ-refined \\
\hline $\mathrm{Li}$ & $2 \mathrm{c}$ & 0 & 0 & 0.5 & $0.965(4)$ \\
$\mathrm{M}$ & $2 \mathrm{c}$ & 0 & 0 & 0.5 & $0.035(4)$ \\
$\mathrm{Li}$ & $2 \mathrm{~b}$ & 0 & 0.5 & 0 & $0.453(2)$ \\
$\mathrm{M}$ & $2 \mathrm{~b}$ & 0 & 0.5 & 0 & $0.547(2)$ \\
$\mathrm{Li}$ & $4 \mathrm{~g}$ & 0 & $0.1716(3)$ & 0 & $0.049(6)$ \\
$\mathrm{M}$ & $4 \mathrm{~g}$ & 0 & $0.1716(3)$ & 0 & $0.951(6)$ \\
$\mathrm{Li}$ & $4 \mathrm{~h}$ & 0 & $0.604(1)$ & 0.5 & $0.986(6)$ \\
$\mathrm{M}$ & $4 \mathrm{~h}$ & 0 & $0.604(1)$ & 0.5 & $0.014(6)$ \\
$\mathrm{O}$ & $4 \mathrm{i}$ & $0.228(2)$ & 0 & $0.215(1)$ & 1 \\
$\mathrm{O}$ & $8 \mathrm{j}$ & $0.245(2)$ & $0.3265(8)$ & $0.2271(9)$ & 1
\end{tabular}

Table 3 (Contd.)

\begin{tabular}{|c|c|c|c|c|c|}
\hline \multicolumn{6}{|c|}{$S=2.2591, R_{\mathrm{B}}=5.122, R_{\mathrm{F}}=2.480, R_{\mathrm{wP}}=15.030$} \\
\hline \multicolumn{6}{|c|}{$a=4.9488(1) \AA, b=8.56458(1) \AA, c=5.02165(6) \AA, \beta=109.0637(1)^{\circ}$} \\
\hline Atom & Site & $x$ & $y$ & $z$ & Occ $_{\text {-refinec }}$ \\
\hline $\mathrm{Li}$ & $2 c$ & 0 & 0 & 0.5 & $0.941(3)$ \\
\hline M & $2 \mathrm{c}$ & 0 & 0 & 0.5 & $0.059(3)$ \\
\hline $\mathrm{Li}$ & $2 b$ & 0 & 0.5 & 0 & $0.514(6)$ \\
\hline M & $2 b$ & 0 & 0.5 & 0 & $0.486(6)$ \\
\hline $\mathrm{Li}$ & $4 \mathrm{~g}$ & 0 & $0.1623(3)$ & 0 & $0.075(6)$ \\
\hline M & $4 \mathrm{~g}$ & 0 & $0.1623(3)$ & 0 & $0.925(6)$ \\
\hline $\mathrm{Li}$ & $4 \mathrm{~h}$ & 0 & $0.667(3)$ & 0.5 & $0.998(2)$ \\
\hline M & $4 \mathrm{~h}$ & 0 & $0.667(3)$ & 0.5 & $0.002(2)$ \\
\hline $\mathrm{O}$ & $4 \mathrm{i}$ & $0.204(2)$ & 0 & $0.219(1)$ & 1 \\
\hline $\mathrm{O}$ & $8 \mathrm{j}$ & $0.257(2)$ & $0.3142(9)$ & $0.2274(8)$ & 1 \\
\hline
\end{tabular}

(F-1)

\begin{tabular}{llllll}
\multicolumn{5}{l}{$S=1.8354, R_{\mathrm{B}}=3.655, R_{\mathrm{F}}=3.172, R_{\mathrm{wp}}=11.935$} \\
\multicolumn{5}{l}{$a=4.9386(5) \AA}$, \\
Atom & Site & $x$ & $y$ & $z$ & Occ-refined $^{\circ}$ \\
\hline $\mathrm{Li}$ & $2 \mathrm{c}$ & 0 & 0 & 0.5 & $0.968(5)$ \\
$\mathrm{M}$ & $2 \mathrm{c}$ & 0 & 0 & 0.5 & $0.032(5)$ \\
$\mathrm{Li}$ & $2 \mathrm{~b}$ & 0 & 0.5 & 0 & $0.509(2)$ \\
$\mathrm{M}$ & $2 \mathrm{~b}$ & 0 & 0.5 & 0 & $0.491(2)$ \\
$\mathrm{Li}$ & $4 \mathrm{~g}$ & 0 & $0.1687(6)$ & 0 & $0.06(2)$ \\
$\mathrm{M}$ & $4 \mathrm{~g}$ & 0 & $0.1687(6)$ & 0 & $0.94(2)$ \\
$\mathrm{Li}$ & $4 \mathrm{~h}$ & 0 & $0.664(3)$ & 0.5 & $0.991(2)$ \\
$\mathrm{M}$ & $4 \mathrm{~h}$ & 0 & $0.664(3)$ & 0.5 & $0.009(2)$ \\
$\mathrm{O}$ & $4 \mathrm{i}$ & $0.272(2)$ & 0 & $0.235(1)$ & 1 \\
$\mathrm{O}$ & $8 \mathrm{j}$ & $0.234(1)$ & $0.3480(6)$ & $0.2184(7)$ & 1 \\
\hline
\end{tabular}

(F-2)

\begin{tabular}{|c|c|c|c|c|c|}
\hline \multicolumn{6}{|c|}{$a=4.93775(2) \AA, b=8.55114(3) \AA, c=5.01752(1) \AA, \beta=109.0085(4)^{\circ}$} \\
\hline Atom & Site & $x$ & $y$ & $z$ & Occ-refined $_{\text {-ris }}$ \\
\hline $\mathrm{Li}$ & $2 \mathrm{c}$ & 0 & 0 & 0.5 & $0.967(3)$ \\
\hline M & $2 \mathrm{c}$ & 0 & 0 & 0.5 & $0.033(3)$ \\
\hline $\mathrm{Li}$ & $2 \mathrm{~b}$ & 0 & 0.5 & 0 & $0.541(5)$ \\
\hline M & $2 \mathrm{~b}$ & 0 & 0.5 & 0 & $0.459(5)$ \\
\hline $\mathrm{Li}$ & $4 \mathrm{~g}$ & 0 & $0.1687(8)$ & 0 & $0.057(5)$ \\
\hline M & $4 \mathrm{~g}$ & 0 & $0.1687(8)$ & 0 & $0.943(5)$ \\
\hline $\mathrm{Li}$ & $4 \mathrm{~h}$ & 0 & $0.664(2)$ & 0.5 & $0.990(6)$ \\
\hline M & $4 \mathrm{~h}$ & 0 & $0.664(2)$ & 0.5 & $0.010(6)$ \\
\hline $\mathrm{O}$ & $4 \mathrm{i}$ & $0.268(1)$ & 0 & $0.235(1)$ & 1 \\
\hline $\mathrm{O}$ & $8 \mathrm{j}$ & $0.231(1)$ & $0.3509(5)$ & $0.2188(6)$ & 1 \\
\hline
\end{tabular}

salt structure $\left(\mathrm{LiMO}_{2}\right)$ with the space group $R \overline{3} m$. However, in this study, the XRD profiles observed with samples 9 and 21 prepared with the two cooling processes exhibited the peaks at around $20-25^{\circ}$. This indicates the ordering of $\mathrm{Li}^{+}$ions in the transition metal layers as a result of cation mixing between the transition metal ions in the transition layer, and $\mathrm{Li}^{+}$ions in the 
Table 4 Summary of the occupancy and occupancy difference of $\mathrm{Li}^{+}$ions at $2 \mathrm{c}, 2 \mathrm{~b}, 4 \mathrm{~g}$ and $4 \mathrm{~h}$ sites. The numbers correspond to those in Fig. 5 : $1-3,11,12,14$, and 15 (yellow), 4, 10, 13, and 16 (pink), and 5-9 and 17-21 (green)

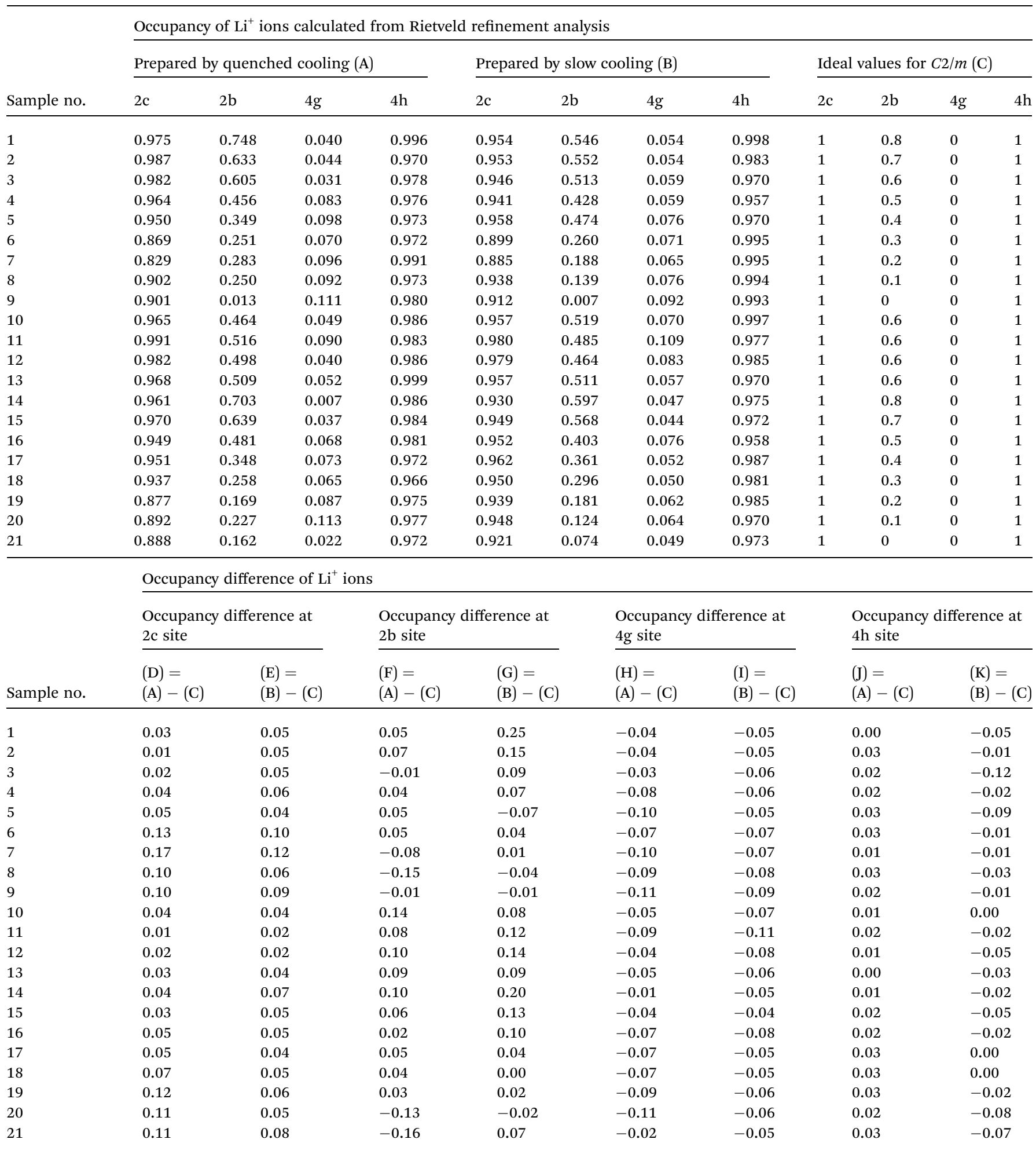

$\mathrm{Li}^{+}$ion layer in the layered $\alpha-\mathrm{NaFeO}_{2}$-type rock salt structure. The appearance of the peaks might result from the synthesis condition for this study. The results of the Rietveld refinement analysis demonstrate excellent fitting between the observed Rietveld refinement profile and the calculated one with a $C 2 / \mathrm{m}$ space group. In particular, the consistency between the XRD 
data and simulated pattern around $20-25^{\circ}$ could be seen in the entire Rietveld refinement, leading to reliable consequences about the Li/Ni mixing degree (Fig. S7 $†$ ).

The occupancies of $\mathrm{Li}^{+}$ions in the $2 \mathrm{c}, 2 \mathrm{~b}, 4 \mathrm{~g}$ and $4 \mathrm{~h}$ sites, whose definitions are explained in Fig. 9 and which were analyzed with Rietveld refinement analysis, of the samples prepared by quenching and slow cooling are summarized in Table 4 . In order to identify the difference in the crystal structure of the samples prepared by different cooling processes, the occupancies of the $\mathrm{Li}^{+}$ions in the $2 \mathrm{c}, 2 \mathrm{~b}, 4 \mathrm{~g}$ and $4 \mathrm{~h}$ sites of the samples were compared with the ideal values for the $C 2 / m$ space group in each composition, and the values are listed in Table 4. By comparing the occupancies listed in Table 4, we tried to find the trend of the preferable cooling process to observe high discharge capacity. Unfortunately, no trend could be found by comparing the occupancies at each site. So, we considered the comparison of the total values of difference between the experimental and ideal values at the $2 \mathrm{c}, 2 \mathrm{~b}, 4 \mathrm{~g}$ and $4 \mathrm{~h}$ sites in each sample to quantify the degree of crystallinity of the samples for the $C 2 / m$ space group. The total difference is defined by eqn (2). The definitions of D, E, F, G, H, I, J and K are the same as those in Table 4.

Total difference $=|\mathrm{D}|+|\mathrm{F}|+|\mathrm{H}|+|\mathrm{J}|$ for the samples prepared by quenching $=|\mathrm{E}|+|\mathrm{G}|+|\mathrm{I}|+|\mathrm{K}|$ for the samples prepared by slow cooling

The total differences in the samples prepared by the quenching and slow cooling processes were plotted. Fig. 10 shows these corresponding plots for the LLO samples prepared by (A) quenching and (B) slow cooling processes. The definition of the colors for the bars is the same as that used for the difference in the discharge capacity between the samples prepared by quenching and slow cooling in Fig. 5 . In the figure, lower bars mean that the crystal structure of the LLO samples take a more ideal structure with the $C 2 / m$ space group. Conversely, when the samples showed higher bars, the samples take on a more disordered structure for the $C 2 / \mathrm{m}$ space group. In (A), samples 1, 2, 3, 11, 12, 14 and 15 (yellow bars) exhibiting higher discharge capacity with the quenched cooling process showed a lower total difference of occupancies among the samples. On the other hand, samples 5, 6, 7, 8, 9, 17, 18, 19, 20 and 21 (green bars) showing higher discharge capacity (when the slow cooling process was used) showed a higher total difference of occupancies among the samples. In (B), samples 1,

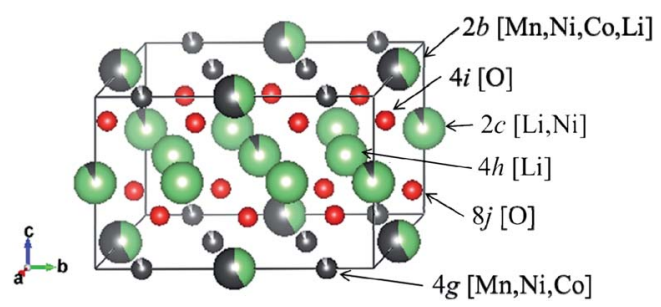

Fig. 9 Definition of the sites occupied by $\mathrm{Li}^{+}$ions in the space group of $\mathrm{C} 2 / \mathrm{m}$.
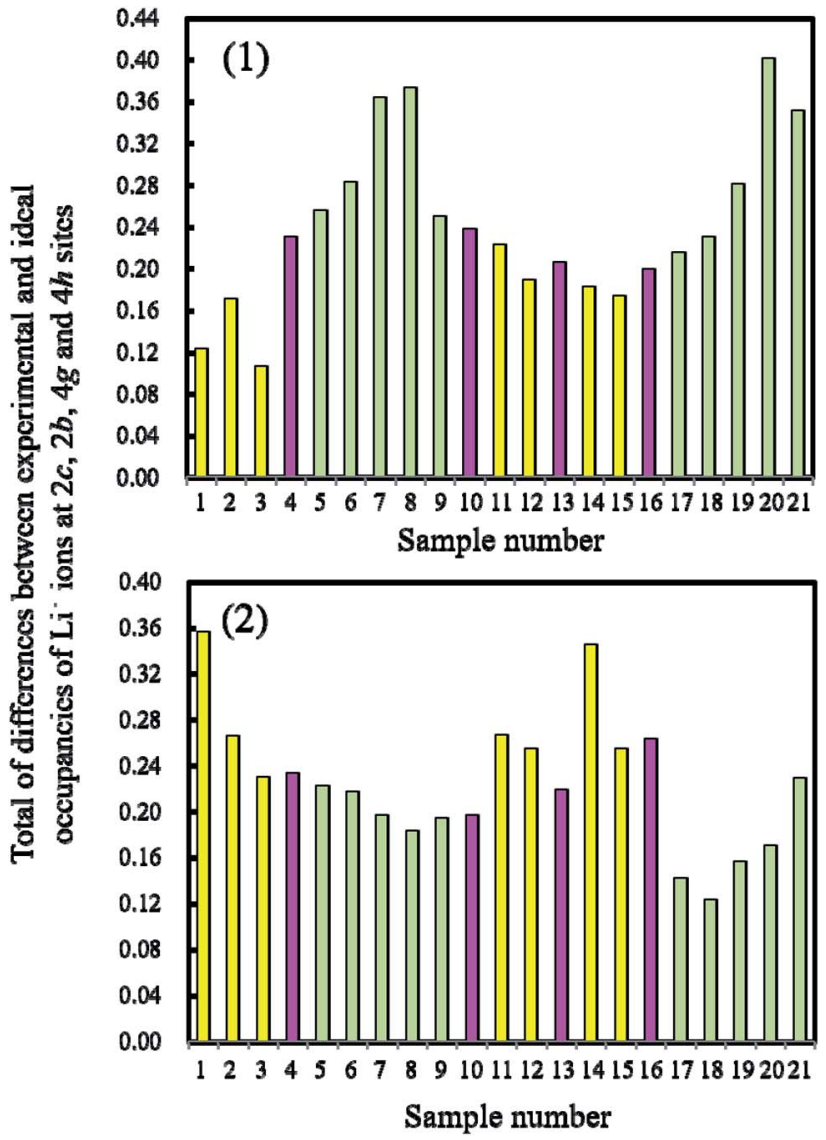

Fig. 10 The total differences between the experimental and theoretical occupancies of $\mathrm{Li}^{+}$ions at $2 \mathrm{c}, 2 \mathrm{~b}, 4 \mathrm{~g}$ and $4 \mathrm{~h}$ sites in the LLO samples. Experimental values were obtained with the samples prepared with the (1) quenched cooling and (2) slow cooling processes. Yellow, pink and green colors correspond to those in Fig. 5, respectively. The experimental and theoretical occupancies of $\mathrm{Li}^{+}$ions at the $2 \mathrm{c}, 2 \mathrm{~b}, 4 \mathrm{~g}$ and $4 \mathrm{~h}$ sites are taken from Table 3 .

2, 3, 11, 12, 14 and 15 (yellow bars) have a higher total difference, and samples 5, 6, 7, 8, 9, 17, 18, 19, 20 and 21 (green bars) have a lower total difference. Samples 1, 2, 3, 11, 12, 14 and 15 tend to approach the ideal structure with the $C 2 / \mathrm{m}$ space group when the samples are quenched. Conversely, when the samples are cooled slowly, their structures develop a low degree of ordering of the crystal structure with the $C 2 / \mathrm{m}$ space group. Samples 5, 6, 7, 8, 9, 17, 18, 19, 20 and 21 show the opposite trend. In addition, as the LLO samples have a more ideal structure with the $C 2 / m$ space group, the samples show higher discharge capacity. Samples 1, 2, 3, 11, 12, 14 and 15 contain a $\mathrm{Li}_{2} \mathrm{MnO}_{3}$ content of over $60 \%$. The content rate of $\mathrm{Li}_{2} \mathrm{MnO}_{3}$ has control over the degree of crystallinity, and the better cooling process for obtaining higher capacity. It has been observed that the LLOs containing the $\mathrm{Li}_{2} \mathrm{MnO}_{3}$ content of over $60 \%$ have the crystal structure, which has the ideal form close to the $C 2 / m$ space group, in the quenched cooling process. However, the LLOs containing the $\mathrm{Li}_{2} \mathrm{MnO}_{3}$ at less $60 \%$ can also have this crystal structure after the slow cooling process. The reason why this is the case is not understood. This question will 
be analyzed with molecular dynamics and density functional theory in our next step.

\section{Conclusions}

In this study, in order to clarify the effect of the cooling process of Li-rich solid-solution layered oxide (LLO) materials on the cathode performance in lithium ion batteries, two types of cooling processes were compared. These two processes were (1) the quenching of the LLO samples with liquid nitrogen, and (2) the slow cooling with the controlled decreasing rate of the temperature in the furnace where the LLO samples were placed. The two cooling processes were each applied to the LLO samples, and then the charging/discharging cycle performance of the LLO samples was obtained. From these results, the necessity of the quenching process for the LLO samples to exhibit high charging/discharging capacities depended on the composition of the LLO samples. As the composition of the tested LLO samples deviated from the composition of the $\mathrm{Li}$

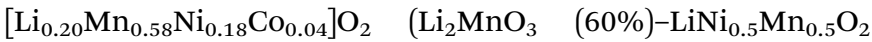
(30\%)- $\mathrm{LiNi}_{1 / 3} \mathrm{Co}_{1 / 3} \mathrm{Mn}_{1 / 3} \mathrm{O}_{2}(10 \%)$ ) sample, which exhibited the highest charging/discharging capacities among the tested LLO samples, the effect of the quenching process on the charging/ discharging capacities became weaker. The LLO samples prepared with the slow cooling process exhibited higher charging/discharging capacities when compared with the LLO samples prepared with the quenching process. The structural analysis of the PXRD patterns of the LLO samples indicated that the samples exhibiting high charging/discharging capacities had a high degree of crystallinity of LLO samples for the space group $C 2 / m$. This means that there was a low degree of cation mixing between the $\mathrm{Li}^{+}$and $\mathrm{Ni}^{2+}$ ions, regardless of the type of cooling process. This study showed that the tendency that a high degree of crystallinity of LLO samples for the space group $C 2 / m$ was needed for the LLO samples to exhibit high charging/ discharging capacities. Furthermore, it was found that the cooling process is not restricted for the LLO samples to exhibit high capacities to the quenching process, and which process is better depended on the composition of the LLO samples. Even in the cooling process for the LLO samples that had the same percentage of $\mathrm{Li}_{2} \mathrm{MnO}_{3}$ in the LLO samples, the necessity of the quenching process was different. There were also samples that needed the slow cooling process to exhibit higher capacities. The reason why the cooling process required for high capacities is different for samples, depending on the composition, is not clear. The elucidation of this question is in progress.

\section{Conflicts of interest}

There are no conflicts to declare.

\section{Acknowledgements}

This work was financially supported by the Kato Foundation for the Promotion of Science, Japan (F. Nomura). The authors are grateful to Dr Toshiaki Ina for help with the QXAFS measurements at BL01B01 of SPring-8 (Proposal No. 2019A1316).

\section{References}

1 M. M. Thackeray, S.-H. Kang, C. S. Johnson, J. T. Vaughey, R. Benedek and S. A. Hackney, $\mathrm{Li}_{2} \mathrm{MnO}_{3}$-stabilized $\mathrm{LiMO}_{2}$ ( $\mathrm{M}=\mathrm{Mn}, \mathrm{Ni}, \mathrm{Co}$ ) electrodes for lithium-ion batteries, $J$. Mater. Chem., 2007, 17, 3112-3125.

2 J. Zheng, J. Xiao and J.-G. Zhang, The roles of oxygen nonstoichiometry on the electrochemical properties of oxidebased cathode materials, Nano Today, 2016, 11, 678-694.

3 L. Riekehr, J. Liu, B. Schwarz, F. Sigel, I. Kerkamm, Y. Xia and H. Ehrenberg, Effect of pristine nanostructure on first cycle electrochemical characteristics of lithium-rich lithiumenickelecobaltemanganeseoxide cathode ceramics for lithium ion batteries, J. Power Sources, 2016, 306, 135147.

4 K. A. Jarvis, Z. Deng, L. F. Allard, A. Manthiram and P. J. Ferreira, Atomic Structure of a Lithium-Rich Layered Oxide Material for Lithium-Ion Batteries: evidence of a Solid Solution, Chem. Mater., 2011, 23, 3614-3621.

5 A. R. Armstrong, M. Holzapfel, P. Novak, C. C. Johnson, S.-H. Kang, M. M. Thackeray and P. G. Bruce, Demonstrating Oxygen Loss and Associated Structural Reorganization in the Lithium Battery Cathode $\mathrm{Li}$ $\left[\mathrm{Ni}_{0.2} \mathrm{Li}_{0.2} \mathrm{Mn}_{0.6}\right] \mathrm{O}_{2}$, J. Am. Chem. Soc., 2006, 128, 8694-8698.

6 J. Hong, H.-D. Lim, M. Lee, S.-W. Kim, H. Kim, S.-T. Oh, G.-C. Chung and K. Kang, Critical role of oxygen evolved from layered Li-excess metal oxides in lithium rechargeable batteries, Chem. Mater., 2012, 24, 2692-2697.

7 F. Nomura, Y. Liu, T. Tanabe, N. Tamura, T. Tsuda, T. Hagiwara, T. Gunji, T. Ohsaka and F. Matsumoto, Optimization of Calcination Temperature in Preparation of a High Capacity Li-rich Solid-Solution Li $\left[\mathrm{Li}_{0.2} \mathrm{Ni}_{0.18} \mathrm{Co}_{0.03} \mathrm{Mn}_{0.58}\right] \mathrm{O}_{2}$ Material and Its Cathode Performance in Lithium Ion Battery, Electrochim. Acta, 2018, 269, 321-330.

8 F. Nomura, Y. Liu, T. Tanabe, T. Gunji, T. Tsuda, S. Ugawa, H. Lee, T. Ohsaka and F. Matsumoto, Elucidation of Key Factors of Water-Resistance of Li-Rich Solid-Solution Layered Oxide Cathode Materials Applicable to a WaterBased Cathode Preparation Process for Li-Ion Battery, Electrochim. Acta, 2018, 283, 478-487.

9 T. Tsuda, H. Kokubun, Y. Asaoka, K. Miyamoto, Y. Mochizuki, T. Gunji, T. Tanabe, S. Kaneko, T. Ohsaka and F. Matsumoto, Dependences of Discharge Capacity, Retention of Discharge Capacity, Average Discharge Voltage and Energy Density, and Rate Capability on the Composition of $x \mathrm{Li}_{2} \mathrm{MnO}_{3}-y \mathrm{LiNi}_{1 / 2} \mathrm{Mn}_{1 / 2} \mathrm{O}_{2}-(1-x-y) \mathrm{LiNi}_{1 / 3} \mathrm{Co}_{1 /}$ ${ }_{3} \mathrm{Mn}_{1 / 3} \mathrm{O}_{2}$ Li-rich Solid-Solution Cathode Materials for LiIon Battery, ECS Trans., 2017, 75(20), 173-187.

10 F. Nomura, T. Tanabe, T. Gunji and F. Matsumoto, Effect of the Cooling Process on the Structure and Charge/Discharge Cycling Performance in $\mathrm{Li}\left[\mathrm{Li}_{0.20} \mathrm{Mn}_{0.58} \mathrm{Ni}_{0.18} \mathrm{Co}_{0.04}\right] \mathrm{O}_{2} \mathrm{Li}$-rich Solid Solution Layered Oxide Cathode Materials for Li-Ion Battery, ECS Trans., 2018, 85(13), 1497-1505.

11 E. McCalla, A. W. Rowe, C. R. Brown, L. R. P. Hacquebard and J. R. Dahn, How phase transformations during cooling 
affect Li-Mn-Ni-O positive electrodes in lithium ion batteries, J. Electrochem. Soc., 2013, 160, A1134-A1138.

12 B. R. Long, J. R. Croy, F. Dogan, M. R. Suchomel, B. Key, J. Wen, D. J. Miller, M. M. Thacheray and M. Balasubramanian, Effect of Cooling Rates on Phase Separation in $0.5 \mathrm{Li}_{2} \mathrm{MnO}_{3} \cdot 0.5 \mathrm{LiCoO}_{2}$ Electrode Materials for Li-Ion Batteries, Chem. Mater., 2014, 26, 3565-3572.

13 Y. Zhang, Y. Zhang, L. Wang, X. He, J. Yang, Y. Jin and K. Zhang, Effect of cooling on the structure and electrochemical properties of $0.3 \mathrm{Li}_{2} \mathrm{MnO}_{3} \cdot 0.7 \mathrm{LiNi}_{0.5} \mathrm{Mn}_{0.5} \mathrm{O}_{2}$ cathode material, Ionics, 2015, 21, 1819-1825.

14 A. Jena, C.-H. Lee, W. K. Pang, V. K. Peterson, N. Sharma, C.-C. Wang, Y.-F. Song, C.-C. Lin, H. Chang and R.-S. Liu, Capacity enhancement of the quenched Li-Ni-Mn-Co oxide high-voltage Li-ion battery positive electrode, Electrochim, Acta, 2017, 236, 10-17.

15 E. McCalla, C. M. Lowartz, C. R. Brown and J. R. Dahn, Formation of layered-layered composites in the $\mathrm{Li}-\mathrm{Co}-\mathrm{Mn}$ oxide pseudoternary system during slow cooling, Chem. Mater., 2013, 25, 912-918.

$16 \mathrm{~N}$. Yabuuchi and T. Ohzuku, Novel lithium insertion material of $\mathrm{LiCo}_{1 / 3} \mathrm{Ni}_{1 / 3} \mathrm{Mn}_{1 / 3} \mathrm{O}_{2}$ for advanced lithium-ion batteries, J. Power Sources, 2003, 119-121, 171-174.

17 Y. Makimura and T. Ohzuku, Lithium insertion material of $\mathrm{LiNi}_{1 / 2} \mathrm{Mn}_{1 / 2} \mathrm{O}_{2}$ for advanced lithium-ion batteries, J. Power Sources, 2003, 119-121, 156-160.

18 X. Li, W. Ge, H. Wang, X. Yan, B. Deng, T. Chen and M. Qu, Enhancing cycle stability and storage property of $\mathrm{LiNi}_{0.8} \mathrm{Co}_{0.15} \mathrm{Al}_{0.05} \mathrm{O}_{2}$ by using fast cooling method, Electrochim. Acta, 2017, 227, 225-234.

19 B. Ravel and M. Newville, THENA, ARTEMIS, HEPHAESTUS: data analysis for X-ray absorption spectroscopy using IFEFFIT, J. Synchrotron Radiat., 2005, 12, 537-541.

20 A. Ito, D. Li, Y. Ohsawa and Y. Sato, A new approach to improve the high-voltage cyclic performance of Li-rich layered cathode material by electrochemical pre-treatment, J. Power Sources, 2008, 183, 344-346.
21 A. Ito, D. C. Li, Y. Sato, M. Arao, M. Watanabe, M. Hatano, H. Horie and Y. Ohsawa, Cyclic deterioration and its improvement for Li-rich layered cathode material $\mathrm{Li}$ $\left[\mathrm{Ni}_{0.17} \mathrm{Li}_{0.2} \mathrm{Co}_{0.07} \mathrm{Mn}_{0.56}\right] \mathrm{O}_{2}$, J. Power Sources, 2010, 195, 567573.

22 C. R. Fell, K. J. Carroll, M. Chi and Y. S. Meng, SynthesisStructure-Property Relations in Layered, "Li-excess" Oxides Electrode Materials $\mathrm{Li}\left[\mathrm{Li}_{1 / 3-2 x / 3} \mathrm{Ni}_{x} \mathrm{Mn}_{2 / 3-x / 3}\right] \mathrm{O}_{2}(x=1 / 3,1 /$ 4, and 1/5), J. Electrochem. Soc., 2010, 157, A1202-A1211.

23 S. Hu, A. S. Pillai, G. Liang, W. K. Pang, H. Wang, Q. Li and Z. Guo, Li-Rich Layered Oxides and Their Practical Challenges: recent Progress and Perspectives, Electrochem. Energy Rev., 2019, 2, 277-311.

24 S. K. Martha, J. Nanda, G. M. Veith and N. J. Dudney, Electrochemical and rate performance study of highvoltage lithium-rich composition: $\mathrm{Li}_{1.2} \mathrm{Mn}_{0.525} \mathrm{Ni}_{0.175} \mathrm{Co}_{0.1} \mathrm{O}_{2}$, J. Power Sources, 2012, 199, 220226.

25 A. Ito, Y. Sato, T. Sanada, M. Hatano, H. Horie and Y. Ohsawa, In situ X-ray absorption spectroscopic study of Li-rich layered cathode material $\mathrm{Li}\left[\mathrm{Ni}_{0.17} \mathrm{Li}_{0.2} \mathrm{Co}_{0.07} \mathrm{Mn}_{0.56}\right]$ $\mathrm{O}_{2}, J$. Power Sources, 2011, 196, 6828-6834.

$26 \mathrm{~W}$. Li, B. Song and A. Manthiram, High-voltage positive electrode materials for lithium-ion batteries, Chem. Soc. Rev., 2017, 46, 3006-3059.

27 N. Ishida, N. Tamura, N. Kitamura and Y. Idemoto, Crystal and electronic structure analysis and thermodynamic stabilities for electrochemically or chemically delithiatedLi $\mathrm{Li}_{1.2-x} \mathrm{Mn}_{0.54} \mathrm{Ni}_{0.13} \mathrm{Co}_{0.13} \mathrm{O}_{2}, \quad J$. Power Sources, 2016, 319, 255-261.

28 M. Tabuchia, Y. Nabeshima, T. Takeuchi, H. Kageyama, K. Tatsumi, J. Akimoto, H. Shibuya and J. Imaizumi, Synthesis and electrochemical characterization of $\mathrm{Fe}$ and Ni substituted $\mathrm{Li}_{2} \mathrm{MnO}_{3}$ - An effective means to use Fe for constructing "Co-free" $\mathrm{Li}_{2} \mathrm{MnO}_{3}$ based positive electrode material, J. Power Sources, 2011, 196, 3611-3622. 